\title{
THE ENEMY WITHIN \\ Personal Rule, Coups, and \\ Civil War in Africa
}

\author{
By PHILIP ROESSLER*
}

\section{INTRODUCTION}

$\mathrm{W}$

HAT explains the outbreak of large-scale political violence between governments and domestic armed opposition? Over the past decade a coherent research program has emerged to address this question. One of its principal findings is that since World War II civil wars have tended to be concentrated in the "rural periphery of poor, post-colonial state[s]." 1 A first wave of quantitative research attributed this empirical regularity to underlying structural factors, such as low income, large populations, mountainous terrain, and cross-border sanctuaries, ${ }^{2}$ rather than to "indicators of ethnic and religious diversity or measures of grievances such as economic inequality, lack of democracy or civil liberties, or state discrimination against minority religions or languages." 3 A second wave of cross-national research, spearheaded by Wimmer, Cederman and $\mathrm{Min},{ }^{4}$ however, challenges the notion that ethnicity is irrelevant in civil wars. Building on the insights of earlier work by Horowitz ${ }^{5}$ and Gurr ${ }^{6}$ and consistent with a large body of quali-

*I thank Andreas Wimmer, Lars-Erik Cederman, and Brian Min for sharing the Ethnic Power Relations data set and Patrick McGowan for sharing his African Military Intervention Events codebook and data file. I am also grateful for helpful comments from Leo Arriola, Nic Cheeseman, Donald Horowitz, Adrienne LeBas, Nic van de Walle, Harry Verhoeven, Andreas Wimmer, and four anonymous reviewers at World Politics. An earlier version of this paper was presented at the 2009 meeting of the American Political Science Association in Toronto.

${ }^{1}$ Fearon 2008, 318.

${ }^{2}$ See Fearon and Laitin 2003; Collier and Hoeffler 2004; Hegre and Sambanis 2006; Salehyan 2007.

${ }^{3}$ Fearon and Laitin 2003, 88. Collier and Hoeffler 2004 had drawn a similar conclusion.

${ }^{4}$ Wimmer, Cederman, and Min 2009; Cederman, Wimmer, and Min 2010.

${ }^{5}$ Horowitz 1985.

${ }^{6}$ Gurr 1993; Gurr 2000.

World Politics 63, no. 2 (April 2011), 300-346

Copyright (C) 2011 Trustees of Princeton University

doi: $10.1017 /$ S0043887111000049 
tative research, they suggest that certain ethnopolitical configurations of power are linked to civil war onset in postcolonial states. Accounting for underlying structural factors, they find that the outbreak of civil war is correlated with the proportion of the population excluded on the basis of their ethnic background. ${ }^{7}$ The work of Wimmer, Cederman, and Min represents a significant development in our understanding of civil war onset as it moves the debate beyond the relationship between ethnic diversity and civil war to the effect of the distribution of power across ethnic groups. Their study raises a new puzzle, however: why do rulers employ ethnic exclusion if it increases the risk of civil war?

Wimmer, Cederman, and Min put forth a broad cultural argument to address this question. They see exclusion to be a function of the rise and spread of the modern nation-state in low-income countries and of the influence of "ethnonational principles of political legitimacythat is, the state is ruled in the name of an ethnically defined people and rulers should therefore care for 'their own people."' Expectations of support increase pressure on incumbents to favor their own ethnic groups in the bureaucracy at the expense of other groups. This ethnonationalism can trigger a cycle of mobilization and countermobilization as opposing groups compete for state control, and it legitimizes policies of ethnic exclusion as a means of preserving one's "rightful" claim to sovereignty. ${ }^{9}$ Wimmer, Cederman, and Min make an important theoretical advancement by placing competition for the state at the center of their analysis. Despite seeming like an obvious pathway of inquiry, the relationship between the struggle for power and large-scale political violence has been undertheorized in the heavily structuralist civil war literature. While they identify a number of "conditions under which struggles over state power may lead to ethnic conflict," they acknowledge that their model fails to account for the "logic of this escalation process." 10 This article fills this gap in the literature.

Focusing on sub-Saharan Africa, a region prone to both internal power struggles and large-scale political violence, the article confirms the strong association between these two phenomena and unravels an important causal process by which bargaining for power leads to civil war. Underlying this civil war pathway is the commitment problem that arises in personalist regimes between elites with joint access to the state's coercive apparatus. Elites have much to gain by parceling

\footnotetext{
${ }^{7}$ Wimmer, Cederman, and Min 2009; Cederman, Wimmer, and Min 2010.

${ }^{8}$ Wimmer, Cederman, and Min 2009, 321.

${ }^{9}$ See also Wimmer 2002.

${ }^{10}$ Wimmer, Cederman, and Min 2009, 334 and 321.
} 
out the state and working together to maintain their hold on power. But they also have a lot to lose if any faction defects from this bargain and conspires to usurp power. Without assurances otherwise, each side maneuvers to protect its share and safeguard against others' firststrike capabilities. Reciprocal maneuvering, however, reinforces suspicion within the regime, often triggering an internal security dilemma that destroys trust and makes eliminating one's rival a vital imperative. Amidst this escalating internal conflict, rulers employ an exclusive strategy to neutralize the existential threat posed by those inside their regime and to secure their grip on power. But the cost of such a strategy, especially when carried out along ethnic lines, is that it forfeits the central government's societal control, leaving it vulnerable to civil war. In short, given the high immediate costs of the coup d'état versus the threat of ethnoregional rebellion in the distant future, the ruler chooses a political strategy that substitutes civil war risk for coup risk.

To test this argument, I use the Ethnic Power Relations data set produced by Wimmer, Cederman, and Min combined with a host of original data on the ethnicity of conspirators of coups and rebellions. I find that in sub-Saharan Africa ethnic exclusion substitutes civil war risk for coup risk. Ethnic exclusion significantly reduces the likelihood that members of a group ${ }^{11}$ will successfully execute a coup, but at the cost of increasing the risk of societal rebellion and civil war. I further show that this result is not merely an artifact of historical inequalities produced by colonial rule (that is, groups excluded since independence are more likely to organize rebellions and groups at the center of power execute coups). Instead I provide evidence that ethnic exclusion and subsequent group rebellion are the outcome of strategic interactions between elites incorporated in the central government, especially coconspirators, who collaborated to seize the state by force but find it difficult to sustain cooperation due to mutual fears that they may be ousted from power in the future. To resolve this commitment problem, African rulers tend to exclude their coconspirators from the central government, though at the cost of increasing the risk of civil war with their former allies. I find that African rulers are four times more likely to purge their coconspirators from the central government than other

\footnotetext{
${ }^{11}$ It is important to note at the outset of this article that when I use the term "[ethnic] group" as the subject of a sentence that is responsible for carrying out actions, such as a coup or rebellion, or as the object and thus as being acted upon (for example, excluded from political power), it should be understood as stylistic shorthand for "members of the group." It is not meant to imply that ethnic groups are monolithic entities that collectively decide to undertake such actions or are uniformly acted upon. I do make the assumption, however, that in the subset of countries under study, in which ethnicity is politically salient, ethnic identity often has a bearing on collective action and political outcomes.
} 
power holders, but at the cost of increasing the risk of group rebellion more than fifteenfold over the next three years. Overall these findings provide empirical support for "one of the most dominant rational theories of civil war - conflict as the result of a commitment problem- [but which] has barely been tested." 12

This article advances the civil war research program and comparative politics more generally in several other important ways. First, it brings together the coup and civil war literatures, which rarely speak to each other, despite the fact that coups and insurgencies represent alternative antiregime technologies that have been highly prevalent in Africa's postcolonial history. ${ }^{13}$ Second, the article highlights the strategic logic of ethnic exclusion. It proposes that rulers are more likely to exclude groups that represent a credible threat to their political survival than other, less powerful ones. While excluding powerful groups is a dangerous game and increases the likelihood of future violent resistance, rulers calculate that this distant threat from society is preferable to an existential one from inside their regimes. Finally, the article incorporates the informal institutions of personal rule, elite accommodation, and ethnic brokerage into the study of civil war. Despite serving as the foundation of political rule in sub-Saharan Africa and generating an extensive scholarly literature, the effect of these institutions on civil war has been understudied.

The rest of the article is divided into four sections. The first part conceives of ethnic power sharing as the foundation of social peace in postcolonial Africa and details the spread of the technology of the coup d'état across the region. The second part theorizes how the shadow of the coup d'état affects elite accommodation and ethnic power sharing. The third part systematically tests several of the principal observable implications derived from the argument. And the conclusion discusses the questions this study raises for future research.

\section{Ethnic Power Sharing and Social Peace in Africa}

Upon independence African rulers faced the challenge, famously described by Migdal, of "strong societies and weak states": ${ }^{14}$ how, under conditions of low economic development, to establish and maintain

\footnotetext{
${ }^{12}$ Blattman and Miguel 2010, 7.

${ }^{13}$ For a recent exception, see Bodea and Elbadawi 2007, in which the authors "embed the study of civil war in a more general analysis of varieties of violent contestation of political power." Missing from their analysis, however, is an appreciation of the variation in risk that different types of contestation pose to the ruler and how this threat differential shapes the political strategies rulers choose.

${ }^{14}$ Migdal 1988.
} 
control of diverse and geographically dispersed societies in the absence of strong political institutions or a unifying national ideology. A legacy inherited from colonialism, African rulers adopted the institutional solution of the colonists to overcome it-clientelism. Facing weak institutional checks on their authority, rulers exploited their discretionary power to parcel out access to the state in exchange for political support. ${ }^{15}$ Informal patronage networks would thereby supersede formal state institutions as the basis of political control. To boost their national legitimacy, subdue growing ethnoregionalism, and extend the regime's societal control, rulers sought to build ethnically inclusive governments in which appointees from rival ethnic groups would play a role similar to that played by tribal chiefs during colonialism, acting as intermediaries between regime and society to facilitate the transfer of local information and mobilize support for the regime. ${ }^{16}$

As many scholars have noted, there was much continuity in the nature of political rule between colonialism and the postindependence period. ${ }^{17}$ Yet at the same time the political game was fundamentally different. Independence led to the opening of the political center and increased groups' demands for self-rule "to avoid trading an old colonialism for a new one." ${ }^{18}$ Ethnic elites rejected indirect rule as an insufficient form of political representation and demanded privileged access to the highest echelons of the central government to credibly guarantee their security and a fair share of state spoils. Thus central to political rule in postcolonial Africa became the institution of elite accommodation, ${ }^{19}$ in which elites from rival groups were not only co-opted into the political system but, unlike during the colonial era, were also incorporated into the highest levels of government. Consequently, the postcolonial state diverged fundamentally from its "apartheid" predecessor ${ }^{20}$ and would become "constructed as a means by which to federate the different ethnic groups via a coalition of their elites." ${ }^{21}$ As illustrated in Figure 1, interethnic elite accommodation, or ethnic power sharing, would represent the modal regime type in postcolonial Africa.

Although, as van de Walle notes, such arrangements "overwhelmingly favored a highly circumscribed political elite and [were] rarely

\footnotetext{
${ }^{15}$ Clapham 1982; Boone 1992.

${ }^{16}$ For seminal works on this mode of political rule, see Lemarchand 1972; and Rothchild and Foley 1988.

${ }_{17}$ Young 1994; Reno 1995.

${ }^{18}$ Horowitz 1985, 188-89.

${ }^{19}$ Bayart 1993.

${ }^{20}$ Mamdani 1996.

${ }^{21}$ Azam 2004, 438.
} 


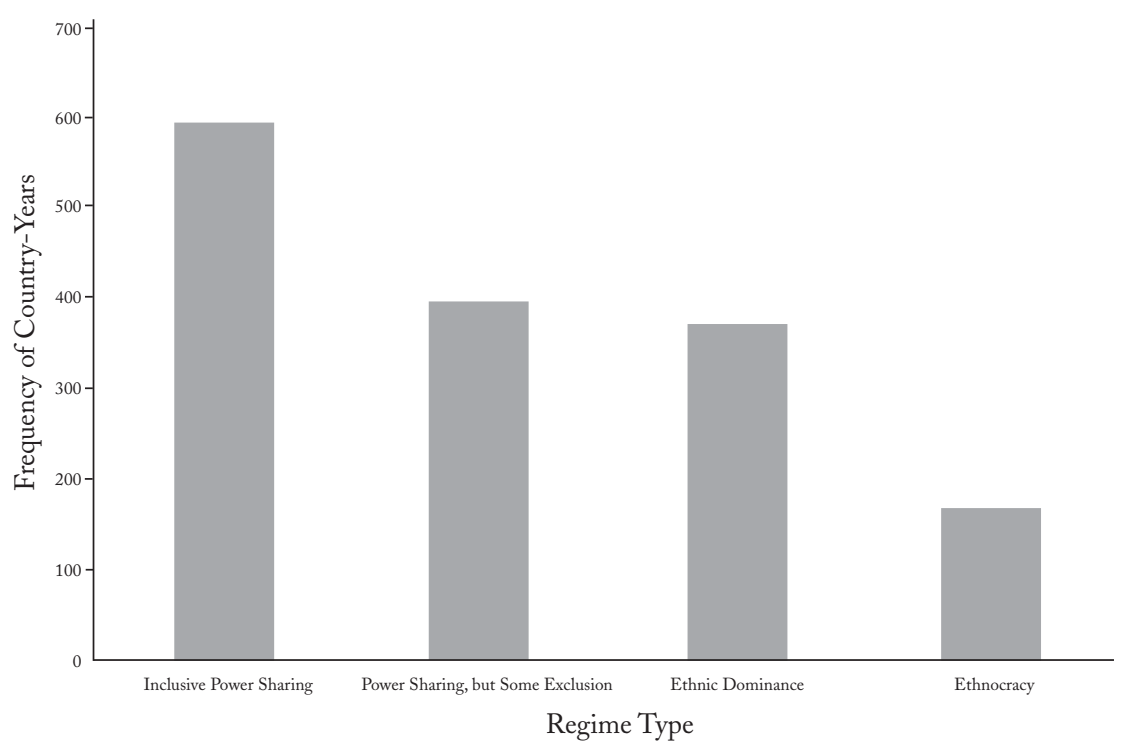

FIGURE 1

Frequency of Regime Types in Sub-Saharan Africa, INDEPENDENCE TO 2005

${ }^{a}$ For coding rules of regime categories, see Appendix 1.

economically redistributive in a meaningful sense," ${ }^{22}$ they would prove mutually beneficial to the ruler and ethnic power holders and, as illustrated in Figure 2, would serve as a key source of social peace. Power sharing demonstrates the ruler's commitment to inclusiveness and boosts his legitimacy as a national figure, while strengthening his societal control through the institution of ethnic brokerage, the personal networks that connect elites co-opted in the center to provincial and community brokers. Power holders, for their part, gain influence at the highest levels of government and access to state resources, which they can employ in turn to finance their own patronage networks and mobilize societal support for the regime.

But if ethnic power sharing provides a win-win solution for rulers and societal elites and undergirds social peace, why, as illustrated in Figure 2, does the arrangement sometimes break down and lead to conflict? I suggest the rise of the technology of the coup d'état and the commitment problem it generates help to explain this puzzle. 


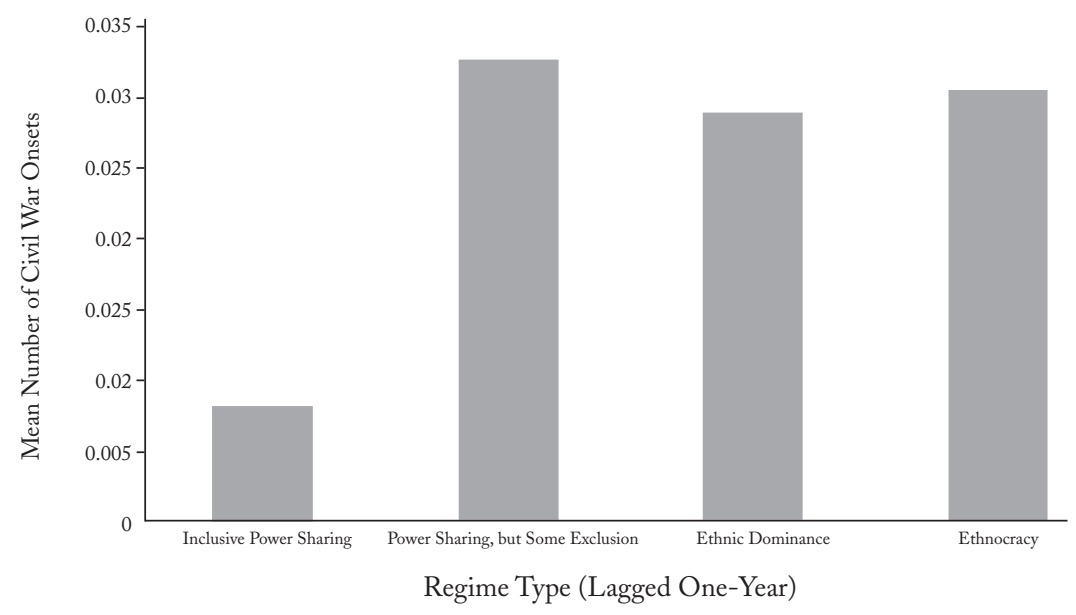

FIGURE 2

Mean Number of Civil War Onsets across Different Regime Types, INDEPENDENCE TO 1999a

Source: Data on civil war onsets are from Fearon and Laitin 2003.

${ }^{a}$ For coding rules of regime categories, see Appendix 1.

\section{The Rise of the Coup d’Etat and the Militarization of ETHNIC BARGAINING}

The transition from colonialism to independence had two major effects on the political game in Africa. As mentioned, it led to the opening of the center and the emergence of elite accommodation as the dominant institution for managing competition for state resources among rival groups. At the same time, however, with the end of colonialism the metropole no longer provided an absolute security guarantee for African governments. ${ }^{23}$ Thus, those with access to the state's coercive apparatus found they faced few constraints to employing force to improve their bargaining position in the struggle for power. This was exemplified in the case of Togo in the first years of its independence, when a group of Kabré veterans from the French colonial army assassinated To-

\footnotetext{
${ }^{23}$ Of course the former colonial powers did not retreat completely. The British and especially the French would sometimes intervene in former colonies to prop up allied regimes. In unreported results, I tested the effect of a group being in a former colony of France, the most interventionist of the former colonial powers, but it has no significant effect on the likelihood a coup is attempted or successfully executed.
} 
go's independence leader and inaugural president, Sylvanus Olympio, setting in motion a significant reversal of the ethnic distribution of power within the Togo government. ${ }^{24}$ The 1963 putsch in Togo coupled with France's nonintervention would set a dangerous precedent for the rest of the continent. The coup d'état, or the sudden and illegal removal of the incumbent using force or the threat of force, came to be viewed as an acceptable and winning strategy in bargaining over power. As in Togo, interethnic coup attempts would emerge as the dominant type of coups in postcolonial Africa ${ }^{25}$ and, as illustrated in Figure 3, ${ }^{26}$ would be the modal source of Ruling Group Transitions ${ }^{27}$ in postcolonial Africa, accounting for nearly 60 percent of such changes.

The spread of the technology of the coup d'état and the militarization of political bargaining would transform the dynamics of elite accommodation and ethnic power sharing in Africa. As Donald Horowitz observes in his seminal work, Ethnic Groups in Conflict: "The strength of the military and its constant proximity to power accord it a kind of counterpoint status to political parties and civilian regimes in struggles for ethnic inclusion and exclusion." ${ }^{28}$ Consequently, while the "strong societies, weak states" problem necessitated that rulers forge interethnic alliances to maintain societal control and underwrite social peace, rulers came to fear that their professed allies, especially those with a foothold in the army, police, or security services, might exploit their regime access and coercive capacity to seize power on their own. ${ }^{29}$

In the next sections I explain how the shadow of the coup d'état and the militarization of elite accommodation undermine ethnic power sharing and give rise to a commitment problem that rulers seek to resolve through a strategy of ethnic exclusion, even at the cost of forfeiting societal control and risking civil war.

\footnotetext{
${ }^{24}$ Horowitz 1985, 482; Decalo 1990, 213-14.

${ }^{25} \mathrm{I}$ find that between independence and 2005, almost two-thirds of the perpetrators of coup attempts (successful and failed) were from outside the ruler's ethnic group.

${ }^{26}$ After the end of the cold war, the source of ruling group transitions changes quite dramatically, as illustrated in Figure 3, though violent seizures of power (coups + rebellions) remain the dominant mode of change.

${ }^{27}$ I consider a ruling group transition to have occurred when the ethnic group(s) or coalition(s) categorized as Senior Partner, Dominant, or Monopoly by the EPR data set is replaced by another ethnic group or coalition. For complete list of ruling group changes, see Roessler 2011, Table I.

${ }^{28}$ Horowitz 1985, 471.

${ }^{29}$ In this article I focus on interethnic bargaining because of its important implications for the likelihood of civil war. In Africa intraethnic coups have also been highly prevalent and pose a similar threat to rulers but with different consequences for societal control and the likelihood of rebellion. In Africa intraethnic civil wars have been very rare.
} 


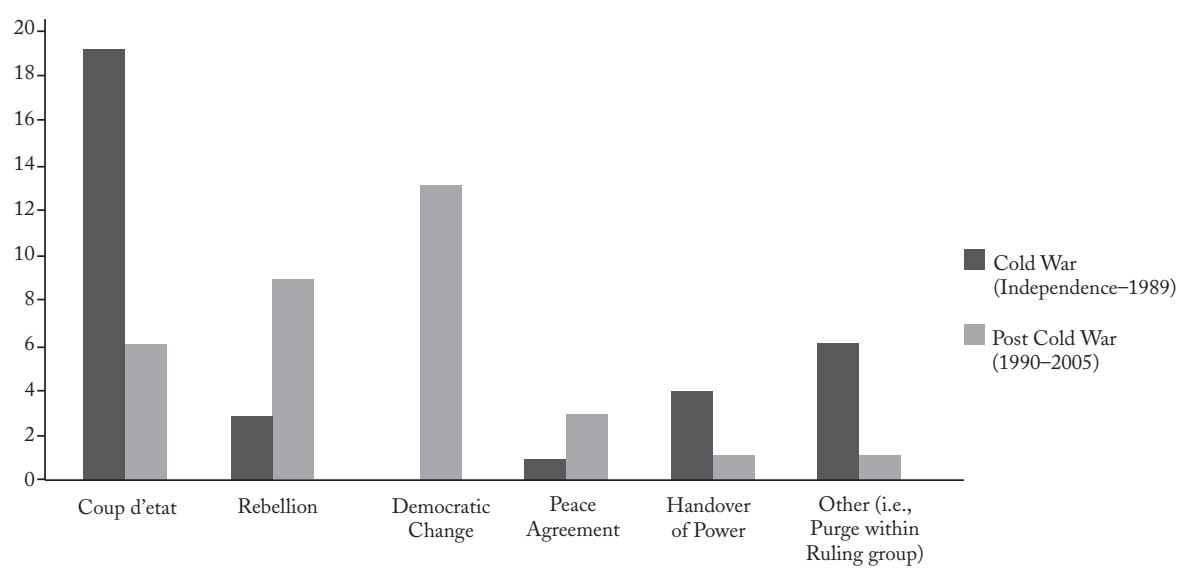

FIGURE 3

Source of Ruling Group Changes in sub-Saharan Africa, INDEPENDENCE TO 2005

\section{In THE SHADOW OF THE COUP D'ETAT}

\section{"Politics of Survival" and the Internal Security Dilemma}

The spread of the technology of the coup d'état has had far-reaching effects on political rule in postcolonial Africa. What makes the coup so dangerous compared with other antiregime technologies, such as mass demonstrations or insurgencies, is connoted by its French meaning, "stroke of state." In contrast to a rebellion, which requires a sustained military operation before it presents a credible challenge to the ruler's grip on power, the coup, as a swift, surprise strike, poses a much more immediate and unpredictable threat, coming not from those based in society but from those inside the government who have the capability to use the state apparatus, especially the military or the police, to depose the incumbent. ${ }^{30}$ The imminence, proximity, and secrecy of the threat, coupled with its incredibly high costs, ${ }^{31}$ have forced rulers to be on the defensive at all times and adopt a set of "coup proofing" techniques, ${ }^{32}$ contributing to what Migdal describes as the "politics of survival." ${ }^{3}$

\footnotetext{
${ }^{30}$ Luttwak 1968.

${ }^{31}$ Between 1956 and 2001, one in four African rulers overthrown faced violent death. Goldsmith 2001.

${ }^{32}$ Horowitz 1985, chap. 13.

${ }^{33}$ Migdal 1988, chap. 6.
} 
Mindful of this ever-present threat to their tenure, rulers pursue policies designed to safeguard their hold on power and neutralize the firststrike capabilities of those within their regimes. For example, one of the most prevalent tactics rulers employ "to prevent threatening centers of power from coalescing" within their regimes, especially in the army, the security services, and the police, is the frequent replacement of cabinet ministers, commanders of armed forces, party leaders, and top bureaucrats. ${ }^{34}$ Two of Africa's longest-serving leaders, Mobutu Sese Seko, the president of Zaire between 1965 and 1997, and Hastings Banda, the president of Malawi from 1964 to 1994, created "atmosphere[s] of perpetual musical chairs" by their frequent reshuffling of ministers in and out of the government. 35 Though costly in terms of government efficiency and productivity, "revolving door" appointments can be an effective political tool, as it prevents clients from amassing too much power within their respective ministries. Moreover, it expands the size of the ruling coalition while minimizing disaffection if the ruler can credibly convince clients that the revolving door to power always remains open, providing those who have been replaced with an incentive to stay in the ruler's favor in hopes of a possible future appointment, rather than defecting and joining the opposition.

Safeguards tend to be less stabilizing, however, if they have the opposite effect and engender suspicions among key stakeholders that the incumbent is maneuvering to concentrate power in the hands of a small ruling clique at their expense and that he may, in the future, shut the door to the apex of the regime. One practice that often raises these fears is "ethnic stacking," or the filling of the most sensitive positions, especially in the security services, the military, and the police, with family members or coethnics. ${ }^{36}$ These individuals are seen as more loyal due to trust developed over years of repeated interactions; embeddedness within the same social networks that facilitates information exchange and makes plotting more difficult; and stronger in-group norms of reciprocity. ${ }^{37}$ The problem with ethnic stacking or other discretionary appointments, however, is that they can be perceived as a conspiracy on the part of the ruler and his allies to build a "shadow state" 38 in order to monopolize wealth and power at the expense of other elites. This

\footnotetext{
${ }^{34}$ Migdal 1988, 214.

${ }_{35}^{35}$ Dickie and Rake 1973, 259, cited in Jackson and Rosberg 1982, 164.

${ }^{36}$ Enloe 1980.

${ }^{37}$ On the microlevel mechanisms of intraethnic cooperation, see Fearon and Laitin 1996; and Habyarimana et al. 2007.

${ }^{38}$ Reno 1998.
} 
leaves those excluded from the shadow state unable to monitor the distribution of patronage and control of coercion and increases their fears that in the future, as the shadow state becomes stronger, they could be completely marginalized from power or face an even worse fate, such as arrest or liquidation. This latter concern is particularly acute if the ruler has a history of employing violence to eliminate rivals.

This dynamic is evident in the early years after Jerry Rawlings and the Provisional National Defence Council seized power in Ghana on December 31, 1981. After the coup Rawlings began to rely heavily on a "small coterie of advisors which included Capt Kojo Tsikata and Tsatsu Tsikata," ${ }^{39}$ two fellow Ewe, to make important decisions, despite the fact that at the time neither was an official member of the PNDC. This increased tension within the regime, as fellow revolutionaries began to question the "conspiratorial and undemocratic character" of this clique and its control of states resources. ${ }^{40}$ Exacerbating unease within the PNDC was the "cold-blooded" murder and immolation on June 30, 1982, of three High Court judges who were targeted for their perceived opposition to the "revolution." 41

In personalist, authoritarian regimes the incumbent's use of his discretionary power to make appointments and eliminate real or perceived rivals increases anxiety within the government. In the absence of any credible guarantees that the ruler and the shadow clique will not turn on them, power holders maneuver to protect their privileged positions and strengthen alliances in anticipation of the eventuality that the ruler will strike. Thus elites seek to build up their own secret networks and parallel security forces. For example, in the late 1960s Uganda's chief of staff of the army, Idi Amin, fearing that President Milton Obote was going to replace him, began to recruit individuals from his home area in the West Nile District, especially from the Lugbara, Madi, Kakwa, and Nubian tribes (mainly Sudanic speakers), to balance against the predominance of soldiers ethnically closer to Obote, namely, those from the Acholi and Langi tribes. By one estimate, between 1968 and 1969 there was a 74 percent increase in Sudanic speakers in the Ugandan army. ${ }^{42}$ Even more, in late January 1970 Amin's deputy and potential successor, Brigadier Pierino Okoya, was found murdered. ${ }^{43}$ While such countermaneuvering is designed to strengthen one's posi-

\footnotetext{
${ }^{39}$ National Reconciliation Commission 2004, 136.

${ }^{40}$ Yeebo 1991, 149-50.

${ }^{41}$ National Reconciliation Commission 2004, 133-39.

${ }^{42}$ Omara-Otunnu 1987, 87.

${ }^{43}$ Kasozi 1994, 102-3.
} 
tion, the downside of such tactics is that they reinforce the incumbent's fears of a possible coup d'état.

Overall, then, elite accommodation in the shadow of the coup d'état can give rise to an internal security dilemma, as power holders, fearful that the other side is going to violate its commitment to sharing power, maneuver to defend their privileged positions. But such action merely increases uncertainty and intrigue that factions in the regime are plotting to seize or consolidate power on their own at the expense of other stakeholders. Rising mutual fears lead allies-turned-rivals to adopt more extreme measures to defend themselves until eventually a point of no return is reached and both sides become convinced that they will be eliminated in the future. At this stage, eliminating one's rival from power is the only viable strategy to guarantee political and personal survival as articulated by Zimbabwe's president, Robert Mugabe, in 1982 about his coalition partner in the midst of an escalating power struggle: "ZAPU and its leader, Dr. Joshua Nkomo, are like a cobra in a house. The only way to deal effectively with a snake is to strike and destroy its head." ${ }^{4}$

In addition to the cases already mentioned, postcolonial African history is replete with examples of the breakdown and violent rupture of elite accommodation, often involving very personal fallouts between friends and comrades-in-arms, such as between Jean-Bédel Bokassa and Alexander Banza in Central African Republic in the late 1960s; Mathieu Kérékou and Michel Aikpe and Javier Assogba in Benin in of the early 1970s; Lansana Conté and Diarra Traoré in Guinea in the mid-1980s; Samuel Doe and Thomas Quiwonkpa in Liberia in the early 1980s; Hissène Habré and Hassan Djamous and Idriss Déby in Chad in the late 1980s; João Bernardo Vieira and his chief of staff of the army, Ansumane Mané, in Guinea-Bissau in 1998; and Robert Guéï and Ibrahim Coulibaly in Côte d'Ivoire in 2000. ${ }^{45}$ In each of these examples the elites cooperated to seize the state, only to experience a violent divorce over their inability to commit to sharing power.

\section{The Dynamics of Violent Rupture and the High Stakes of THe "Retrieval Coup"}

Although the dynamics of violent rupture can take various forms, the cases mentioned above point to a common pattern. As the internal security dilemma escalates, the incumbent moves to mitigate the per-

\footnotetext{
${ }^{44}$ Lelyveld 1982.

${ }^{45}$ Invaluable sources on these cases include the following: Titley 2002; Decalo 1995; Ellis 1999; Burr and Collins 1999; Decalo 1997; Prunier 2009; Reyntjens 2009; Forrest 2003; and Langer 2004.
} 
ceived threat posed by his rival by demoting or removing him from a position of influence. For example, in late 1970 Obote transferred Idi Amin from chief of staff to chief of defense of staff; in 1983 Doe made a similar move against his lifelong friend and coconspirator, Quiwonkpa, demoting him from commander of the army to secretary general of the People's Redemption Council; in July 1998 Laurent Kabila shifted James Kabarebe, his Rwandan comrade-in-arms, from chief of staff of the Forces Armées Congolaises to special military adviser. In addition to diminishing the rival's authority, such public demotions serve a valuable strategic purpose: as the internal rivalry reaches a breaking point, rulers aim to label the rival as the losing horse and a dangerous bet for those who are on the fence. For the rival and his allies, including coethnics, military subordinates, party members, and disciples, whose fate is often linked to that of their patron, such a loss of power and prestige is an incredible act of betrayal by the ruler. After all, it was they, as his former comrades, who made the ruler who he is. Without them, they think, the incumbent would be nothing. Feeling betrayed and cornered, they see no alternative but to use force to restore the proper power balance, with themselves at the apex of the state. With the window of opportunity to strike at the heart of the regime rapidly closing, the rivals make an eleventh-hour bid for power. As suggested anecdotally by the examples mentioned, however, these desperate attempts to gain power prove to be losing battles as the ruler, having exploited his incumbency advantage as the security dilemma intensified, effectively secured his hold on power.

\section{The Strategic Logic of Ethnic Exclusion}

Despite having anticipated the possibility that their rivals may try to violently seize power and even put in place mechanisms to safeguard against such an eventuality, the ruler experiences a profound psychological reaction to the near loss of power. Similar to the emotions felt by their rivals, the ruler feels a sense of betrayal, fear, and revenge. An excerpt from Hissène Habré's speech in the wake of the April 1, 1989, coup by two of his closest former aides, Hassan Djamous and Idriss Déby, is revealing on this point:

You should also know that these enemies are here. They are not to be found abroad. They are close to us and even within our ranks, because recent events have revealed the treachery of Djamous, Idris, and Itno. These are people who were brought to the forefront by this revolution. Yes, the revolution gave them an identity, a personality, renown, honours, and greatness. And they took great advantage of the benefits of our struggle, of the sweat and the blood of our 
armed forces and our people to enrich themselves, [only] to stab Chad in the back. $^{46}$

Emotionally shaken and paranoid about the possibility of subsequent threats to their survival, rulers desperately seek to reinforce their grip on power and purge their regimes of all disloyalists. Rulers face an information problem, however: how are they to identify disloyalists when these individuals have a strong incentive to conceal their true loyalties? Given the heightened sense of threat and the high level of uncertainty, the ruler feels there is little room for error. One information shortcut among many that rulers may fall back on is ethnic identity, particularly when ethnicity is perceived to be structuring conflict within the regime. ${ }^{47}$ Suspecting that his rival's coethnics are sympathetic to the plotters' political objectives and may have collaborated in their bid for power, the ruler moves to purge them from the regime in order to nullify the risk of a future internal challenge. Accordingly, ethnic exclusion serves as an expedient mechanism to eradicate perceived enemies at a time of high uncertainty and when the ruler's time horizon is incredibly short.

For example, in Burundi in 1965 after a coup attempt by a group of Hutu army and gendarmerie officers, the ruling Tutsi elite went to great lengths to eliminate Hutu from the government, thus destroying the ethnic balance that had existed within the regime in the first years after independence and turning Burundi into what Horowitz calls an "ethnocracy." ${ }^{8}$ As Lemarchand explains:

The mutineers took a huge gamble and lost—but the losses involved far more than the extermination of thousands of Hutu after the aborted coup. Also lost was an opportunity for the Hutu leadership to share in the exercise of power. After the extensive purges of the army and gendarmerie and the physical elimination of every Hutu leader of any standing, power became the exclusive monopoly of Tutsi elements. ${ }^{49}$

For the next twenty-eight years, Hutu were completely locked out of power and thus posed no internal threat to Tutsi rule. The Burundi

\footnotetext{
${ }^{46}$ BBC Summary of World Broadcasts 1989.

${ }^{47} \mathrm{In}$ theorizing the role of ethnicity in these political power struggles, I am not arguing that competing elites are necessarily motivated by ethnic aims; instead, my argument is more in line with the logic put forth by Henry Hale, who conceives of ethnicity "as an uncertainty-reduction device [that provides] convenient ways for people to organize interest-based competition and/or understand who is on which side in such competition without these categories actually being the driver or cause of that competition"; Hale 2010, 2, emphasis in original. See also Hale 2008.

${ }^{48}$ Horowitz 1985.

${ }^{49}$ Lemarchand 1994, 71.
} 
case exemplifies Horowitz's maxim that "[o]nce an ethnocratic regime is in power, opposition [from rival groups] is not likely to make its will felt through further coups." ${ }^{50}$

A similar pattern is seen in Liberia after Quiwonkpa's 1985 coup attempt against Doe. State security services purged Quiwonkpa's Gio kinsmen and the linguistically related Mano from the armed forces and indiscriminately massacred civilians from these ethnic groups. In the months and years after the coup attempt, Doe restructured his regime, filling the gap left by the exclusion of clients from the Gio and Mano with his Krahn coethnics and the Mandingo, who as "outsiders" were seen as nonthreatening and more "trustworthy." Meanwhile, the Gio were almost completely excluded from the government, "since they were suspected of disloyalty to President Doe." 51 A similar fate was met by the Malinké in Guinea after the 1985 coup by Traoré; by the Zaghawa in Chad after the 1989 coup by Djamous and Déby; and by the Yakoma in Central African Republic after a coup attempt in 2001 by soldiers loyal to former president, André Kolingba.

In addition to physically insulating the ruler, ethnic exclusion can serve two other critical functions. As a form of "collective liability, or group punishment" 52 against the coup plotters and their coethnics, it can serve a communicative role and signal to other potential dissidents the collective costs of daring to challenge the regime. Finally, ethnic targeting can help to shore up support within the ruler's ethnic group. Labeling the ethnic challengers as "an enemy that needs to be destroyed before they can destroy us," rulers emphasize the importance of group solidarity and the potential ruinous consequences disunity will have in the face of an existential threat. This rhetoric can incite communal violence and ethnic pogroms, as members interpret it as a signal to attack those from the identified group.

Risking Civil War

Overall, exclusion is a short-term strategy designed to strengthen the incumbent's grip on power and terminate the internal security dilemma that emerges between allies-turned-enemies. But, of course, such a strategy does not resolve the underlying conflict over the distribution of power and wealth between competing elites and their constituencies. Instead, it merely displaces this conflict from within the regime to society, where the ruler and his allies calculate it poses less of a threat

\footnotetext{
${ }^{50}$ Horowitz 1985, 499.

${ }^{51}$ Ellis 1999, 66.

${ }^{52}$ Fearon and Laitin 1996, 727.
} 
to their political supremacy. The key downside of exclusion, especially when it is carried out along ethnic lines, is that it tends to facilitate insurgency formation, while compromising the regime's counterinsurgency capabilities. In other words, it leaves the regime vulnerable to a future civil war.

The regime's exclusive practices facilitate insurgency formation in several ways. Purges and defections generate a pool of disaffected elites who can serve as dissident entrepreneurs and use their experience and skills to raise the political consciousness among the excluded group, set a revolutionary agenda, and help to organize a rebel group..$^{53}$ Moreover, these former regime insiders are familiar with the inner workings of their enemy and can use this information to attack the government at its points of weakness. Their prior government experience provides them with the clout to deal with neighboring governments and other foreign patrons whose financial and military support is often indispensable for the group to sustain a private army. For example, after fleeing to Darfur in the wake of the April 1 failed coup in 1989, Idriss Déby, who had been the liaison between anti-Gadaffi dissidents in Chad and the Chadian government, traveled to Tripoli, where he divulged valuable information to Libyan security officials about American and Chadian anti-Libyan operations and was repaid with crucial military support for his nascent insurgency. ${ }^{54}$

Though dissident entrepreneurs may have to look to foreign governments for financing and military hardware, they usually have little difficulty in recruiting individuals to join the rebellion, given that many of their ethnic kinsmen face persecution after the violent breakdown of the regime. State violence, particularly when applied indiscriminately, creates an incentive structure for individuals to join a violent organization, because they "can no longer assure themselves of immunity from repression by simply remaining politically inert." ${ }^{55}$ Hissène Habrés indiscriminate violence against the Zaghawa after the April 1 coup attempt drove many to join Déby as he set up camp in Darfur. ${ }^{56}$ Insurgency formation in Zimbabwe in the early 1980s was fomented by state repression against perceived "dissident sympathizers" and "disloyal agents" after the discovery of an arms cache and a failed assassination attempt on President Robert Mugabe in 1982.57

\footnotetext{
${ }^{53}$ Lichbach 1995.

${ }^{54}$ Africa Confidential 1989. See also the entry on Idriss Déby, in Decalo 1997, 148.

${ }^{55}$ Mason and Krane 1989, 176.

${ }^{56}$ Amnesty International 2001.

${ }^{57}$ Alexander 1998, 156.
} 
Not only does ethnic exclusion facilitate the organization of insurgency, but it also weakens the regime's counterinsurgency capabilities, tilting the battlefield in the dissidents' favor. An exclusive strategy undermines the ethnic brokerage networks that are critical for societal control in the absence of strong state institutions. The breakdown of these clientelist networks leaves the regime bereft of locally trusted brokers who are crucial to mobilizing local support for the regime and for credibly communicating with the dissidents. Moreover, given the geographic concentration of many ethnic groups in Africa, when exclusion follows ethnic lines it not only compromises societal leverage but it also forfeits control of terrain, which provides the insurgents with invaluable space from which to organize and launch military operations. To compensate for the loss of societal and territorial control, the ruling elite come to rely more heavily on their coethnics or regional rivals of the excluded group to serve as the key interlocutors. But often these "foreign" or regional intermediaries are a poor substitute for intraethnic brokers. ${ }^{58}$ Even if they have familiarity with the local terrain, their inability to penetrate the rivals' ethnic networks makes it difficult for them to acquire accurate information about dissident activities carried out by members of the excluded group..$^{59}$

As dissidents organize an insurgency, find space to operate, and receive local support, the regime finds itself lacking the local leverage and access to information necessary to produce selective violence and contain the rebellion. ${ }^{60}$ Instead, the regime has little choice but to resort to indiscriminate violence. Though over the long run indiscriminate violence may slow the rebellion, in the short term it often inflames the conflict, as it drives individuals and communities to support the rebels ${ }^{61}$ and triggers full-scale civil war.

\section{SUMMARY AND OBSERVABLE IMPLICATIONS}

Overall this article proposes that a subset of civil wars in sub-Saharan Africa is rooted in the commitment problem that arises as elites with joint control of the state's coercive apparatus bargain over power and wealth. Civil war is a consequence of the political strategy rulers choose to resolve this commitment problem and secure their hold on power.

\footnotetext{
${ }^{58}$ See Fearon and Laitin 2011. 2010.

${ }^{59}$ On the efficacy of tapping into ethnic networks for counterinsurgency operations, see Lyall

${ }^{60}$ Kalyvas 2008.

${ }^{61}$ Goodwin 2001.
} 
This argument produces two important and testable observable implications. The first is the general hypothesis that ethnic exclusion effectively reduces the risk of the coup though at the cost of increasing the risk of the civil war.

H1. Ethnic exclusion substitutes civil war risk for coup risk.

The second implication is that rulers are more likely to employ ethnic exclusion against groups that possess coup-making capabilities, including the very friends and allies who put them in power-their coconspirators - than against other, less threatening groups.

H2. Rulers are more likely to exclude groups with a foothold in the state's coercive apparatus than other less threatening groups, though at the cost of increasing the likelihood of a future civil war with the targeted group.

\section{EMPIRICAL ANALYSIS}

\section{RESEARCH DESIGN}

I test these hypotheses at the group level across thirty-five sub-Saharan African countries using data from the Ethnic Power Relations (EPR) data set built by Wimmer, Cederman, and Min. The EPR "identifies all politically relevant ethnic categories around the world and measures access to executive-level state power for members of these ethnic categories in all years from 1946 to 2005." ${ }^{\prime 2}$ It covers only countries and time periods within countries "in which political objectives, alliances or disputes" are "framed in ethnic terms," thus "avoiding an ethnic lens for countries not characterized by ethnic politics, such as Tanzania and Korea." ${ }^{63}$ For sub-Saharan Africa, EPR covers 35 countries, 220 groups, and 7197 group-years. ${ }^{64}$ It excludes data on Burkina Faso, Cape Verde, Comoros, Djibouti, Equatorial Guinea, Lesotho, Mauritius, Seychelles, São Tomé and Príncipe, Somalia, Swaziland, and Tanzania, either because the countries do not meet the size criteria (a population of at least one million and a surface area of at least half a million square kilometers as of 2005) or because ethnicity is considered to be of low salience. I also exclude Botswana because only one ethnic group, the San, is considered politically relevant.

\footnotetext{
${ }^{62}$ Wimmer, Cederman, and Min 2009, 325.

${ }^{63}$ Wimmer, Cederman, and Min 2009, 326.

${ }^{64}$ This excludes all group-years in which the group is labeled "irrelevant" in previous year, periods of state collapse, and the first year of independence, since many variables are lagged.
} 


\section{OPERATIONALIZING KEY VARIABLES}

Derived from a survey of nearly one hundred experts of ethnic politics, the EPR codes each ethnic group or coalition "according to the degree of access to central state power by those who claimed to represent them" for a given year. ${ }^{65}$ Access to power is coded as a seven-point categorical variable. Categories include Monopoly, Dominant, Senior Partner, Junior Partner, Regional Autonomy, Powerless, or Discriminated.$^{66}$ To examine the effect of a group's access to power and its ability to carry out coups versus participate in civil wars, I collapse the seven-point variable into a dichotomous variable, Inclusion. Groups with access to central state power (that is, coded as Monopoly, Dominant, Senior Partner, or Junior Partner) are scored 1, while all others (Regional Autonomy, Powerless, or Discriminated) are scored 0.

To determine the relationship between access to power and a group's ability to execute coups versus rebel, we need data on the ethnicity of those who lead coup attempts (both failed and successful) and the ethnicity of those who participate in civil wars. I construct three variables to reflect this: GroupScoup, GroupFcoup, and GroupRebel. GroupScoup and GroupFcoup indicate whether members of a given ethnic group executed a successful or failed coup attempt, respectively, against the incumbent in that year. To code these variables, I use data from Patrick McGowan's database on coup attempts in Africa. ${ }^{67}$ Using the case materials shared by McGowan and additional secondary sources, ${ }^{68} \mathrm{I}$ then score GroupScoup and GroupFcoup based on the ethnicity of the leaders or executors of the coup attempts (or at least those identified as the coup plotters by the press and secondary sources). ${ }^{69}$ If members of

${ }^{65}$ Access to central state power "focuses only on executive-level power, that is, representation in the presidency, cabinet, and senior posts in the administration, including the army. . . In all cases, coders focused on absolute access to power irrespective of the question of under- or overrepresentation relative to the demographic size of an ethnic category." See Wimmer, Cederman, and Min 2009, 326.

${ }^{66}$ For a definition of these various categories, see Wimmer, Cederman, and Min's Online Appendix, at http://www.sscnet.ucla.edu/soc/faculty/wimmer/.

${ }^{67} \mathrm{McG}$ Gowan's coup d'état data set tracks successful coups, failed coup attempts, and coup plots for all sub-Saharan African countries between 1956 and 2004. In systematizing coup attempts, McGowan focuses on "events in which existing regimes are suddenly and illegally displaced by the action of a relatively small group, in which members of the military, police or security forces of the state play a key role, either on their own or in conjunction with civilian elites such as civil servants, politicians and monarchs." See McGowan 2003, 343, emphasis added. Importantly, his definition does not take into consideration the level and production of violence associated with the coup, which would possibly conflate coups d'état with civil wars.

${ }^{68}$ Particularly useful were the Historical Dictionaries of Africa series by Scarecrow Press and the various years of Africa Contemporary Record published by Holmes \& Meier. Evidence and sources to support coding decisions are available online at Roessler 2011.

${ }^{69}$ The leaders of the coup are not necessarily the same as the person who becomes president after the coup. 
an ethnic group were leaders of the successful or failed coup attempt in a given year, the group is scored a one on GroupScoup or GroupFcoup, respectively. ${ }^{70}$ Otherwise it receives a zero.

Several important caveats are in order here. In undertaking this exercise, I am not suggesting (1) that all coup plotters are motivated by ethnic grievances; (2) that their ethnicity is their dominant political identity; or (3) that they necessarily represent the interests of their group or even have overwhelming support from their coethnics. As is evident from a reading of the cases, coup attempts can take a variety of forms, ranging from a brazen individual acting on his own out of personal interest, to a coalition of military elites who come from a cross-section of societal groups and are driven by corporate concerns (for example, Gambia in July 1994), to a group primarily from one ethnic group whose members are acting to preserve or restore their preeminent political position (for example, Burundi 1965 or Cameroon 1984). Whatever the motivation for the coup attempt, however, we cannot expect the ethnicity of the conspirators or plotters to be completely irrelevant, especially given that the analysis covers a subset of countries in which ethnicity is politicized. To execute a successful coup d'état requires having access to sensitive points inside a regime or at least having allies in these positions and being able to convince significant sections of the army and regime to join the movement (or at least not to resist). Thus, we would expect a regime's ethnic political configuration to have some mediating effect on whether an individual has the inside access or connections to lead such an attempt. Moreover, a coup leader's ethnic identity may affect how a plot or attempt is perceived by other key actors, especially the ruling group, even if the conspirators do not have an "ethnic agenda." An incumbent may perceive or declare an "ethnic plot" even when one does not exist because of poor information or as an expedient mechanism to mobilize support from his own ethnic group.

I carry out a similar exercise to code GroupRebel. This variable captures whether members of a given ethnic group are the leading and significant participants in a large-scale insurgency (that is, one that leads to a civil war) against the central government. I code the first year members of the ethnic group join the insurgency and engage in large-scale violence against the government. ${ }^{71}$ Multiple groups may

\footnotetext{
${ }^{70}$ See Roessler 2011, Table II, which provides information on the ethnicity of coup leaders.

${ }^{71} \mathrm{I}$ consider an ethnic group to engage in large-scale violence that reaches the level of civil war if in the first three years of its participation in an insurgency the rebellion leads to one thousand battlefield deaths, consistent with Sambanis 2004, 829-30. For the start date, I employ Sambanis's rule that "the
} 
participate in a single insurgency, but they do not all necessarily become involved in the same year. For example, in the civil war in Sudan between the Sudan People's Liberation Army (SPLA) and the central government in Khartoum that began in 1983, members of the Dinka, Nuer, and Shilluk are coded as participating in the rebellion that led to large-scale political violence with the government's armed forces in 1983, but members of the Nuba do not become significantly involved until 1987, when the SPLA makes inroads into that community and large-scale violence breaks out in the Nuba Mountains over the next three years. For a complete list of rebellion onsets and the ethnicity of the rebels, see the Online Appendix. ${ }^{72}$

\section{Empirical Analysis: Ethnic Exclusion and the Relative Risk of Coups versus Rebellions}

\section{BIVARIATE RELATIONSHIPS}

With data on ethnic groups' access to power, the ethnicity of coup leaders, and the ethnicity of insurgencies, we can test the first hypothesis. Is there evidence that a group's inclusion or exclusion from power affects its members' abilities to execute a coup or insurgency? Figure 4 compares the mean level of successful coups and the mean level of rebellions by members of an ethnic group in a given year as a function of their access to power or their exclusion from power in the previous year. It illustrates quite starkly the trade-off rulers face: on average, ethnic exclusion reduces a group's likelihood of seizing power in a coup d'état but at the cost of significantly increasing the likelihood of a societal rebellion that becomes a full-scale civil war. ${ }^{73}$ Figure 5 provides an-

start year of the war is the first year that the conflict causes at least 500 to 1,000 deaths. If the conflict has not caused 500 deaths or more in the first year, the war is coded as having started in that year only if cumulative deaths in the next 3 years reach 1,000." To determine whether the beginning of the insurgency led to one thousand battlefield deaths, I refer primarily to the Uppsala Battle Deaths Best Estimate, which often provides information on the insurgent groups that are active in a given conflict for each year. This allows me to make a determination about when groups enter or leave a conflict. Where the Uppsala Battle Deaths Dataset is vague about which insurgent groups are active, I rely on country-specific materials and interviews with country experts to evaluate which insurgencies are active and the ethnic support for the movements. Finally, if Uppsala Battle Deaths Dataset does not mention a conflict, but both the Fearon and Laitin 2003 and the Sambanis data sets do, I also include the case. On the Uppsala Battle Deaths Dataset, see Lacina and Gleditsch 2005.

${ }^{72}$ Roessler 2011, Table III.

${ }^{73}$ As is evident in Figure 4, exclusion does not appear to have as substantial an effect on reducing coups as inclusion does on reducing rebellion. Why is this? This is primarily a function of the fact that EPR is a measure of a group's access to political power but not necessarily of its representation in the military. Thus a significant subset of the incidences of excluded groups executing coups are cases in which groups are politically excluded from the central government but still have a substantial presence in the military, such as the Kabré in Togo in early 1960s, Northerners in Benin in 1960s, Temne and 


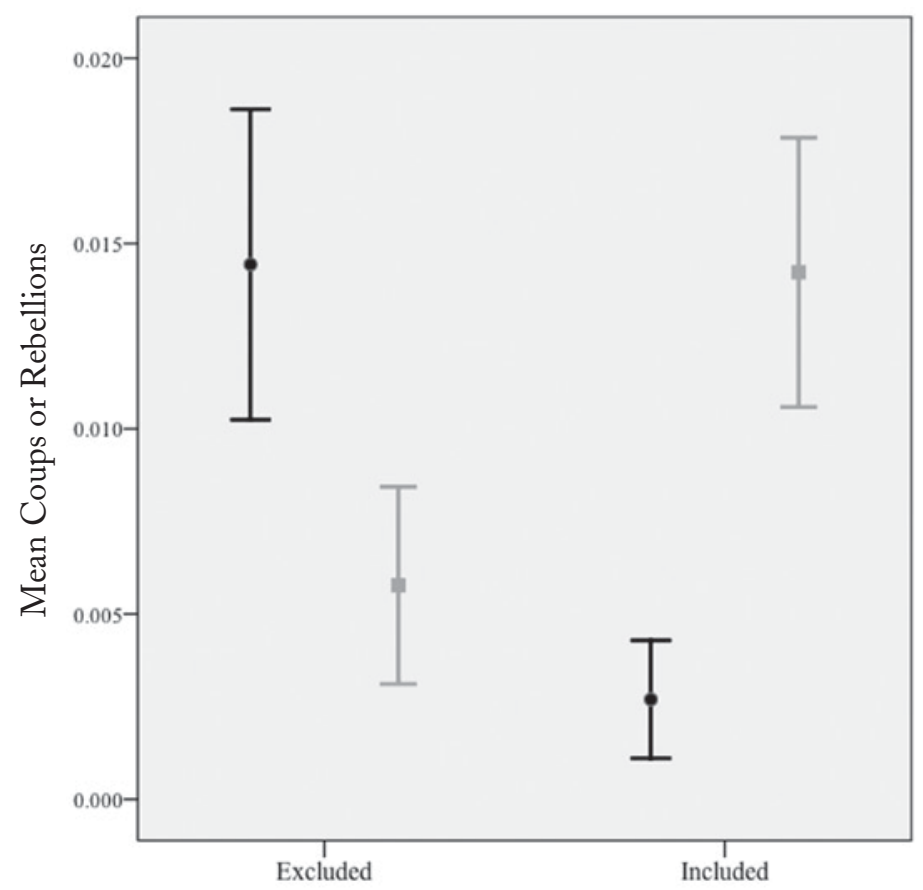

I GroupRebel I GroupScoup

FIGURE 4

Substitution Effect of Ethnic Exclusion: Rebellion Risk for Coup RisK ${ }^{\mathrm{a}}$

${ }^{\text {a }}$ Bars represent $95 \%$ confidence intervals.

other way to examine the effect of ethnic exclusion on a group's ability to carry out a successful coup d'état. It illustrates not only that groups excluded from the central government attempt fewer total coups (60 percent fewer compared with groups inside the government) but also that their success rate is lower (38 percent compared with 55 percent for groups inside). Not having access to the central government reduces the likelihood of a coup attempt and hinders its efficacy.

\section{REGRESSION ANALYSIS AND DISCUSSION OF RESULTS}

Moving beyond the simple, but revealing, bivariate tests, I turn to a set of logistic regressions in order to control for other potential explanatory variables that capture both group and country characteristics (see

Limba in Sierra Leone in late 1960s, the Balanta in Guinea-Bissau in late 1970s, indigenous groups in Liberia late 1970s, and Northerners in Côte d'Ivoire in late 1990s. This is obviously an explosive combination. For a discussion of the grievances this incongruity can generate, see Forrest 1987 on the Balanta. See also Horowitz 1985, chap. 11. 


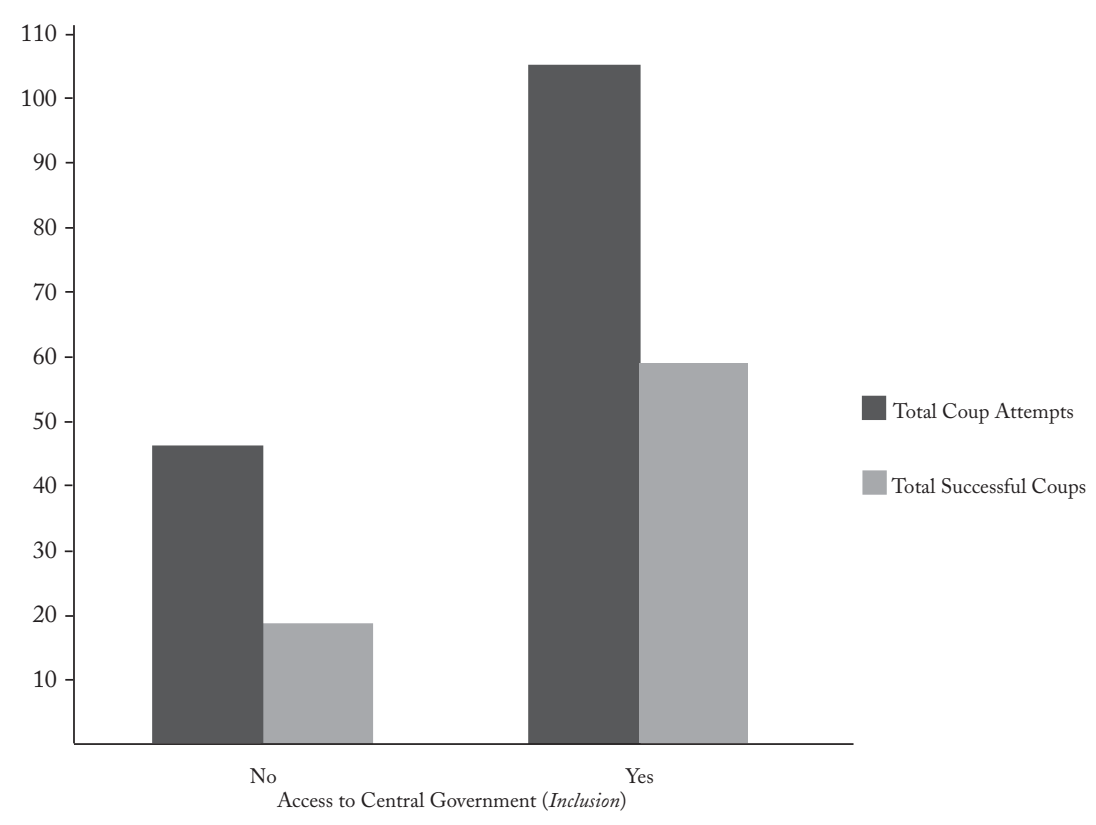

FIGURE 5

Access to Central Government and Coup Efficacy

Table 1). I first run two sets of estimations (models $1-7)$ that regress successful coups (GroupScoup) and group rebellions (GroupRebel) on an EPR group's access to the central government, while also including various control variables. In models 1-7, I include group-level variables controlling for the size of the ethnic group as a proportion of population (Group Size) and the number of ethnic groups sharing power in the central government (Center Segmentation). ${ }^{74}$ I then add countrylevel variables controlling for income level (Log Income) and population size (Log Population). Since data on $\log$ Income are missing for some group-years, which causes about 6 percent of the observations to be dropped, I run separate models (models 2, 3, 6, and 7) with the inclusion of these variables. In model 4 I add a variable, Ruler Ethnic Group, to control for whether the ruler of the country is of the given group. This variable allows us to check if coups from insiders are merely a function of intraethnic contests for power. In models 3-7, I run the full

\footnotetext{
${ }^{74}$ The data for these two variables come from Wimmer, Cederman, and Min 2009; and Cederman, Wimmer, and Min 2010. They find that group size and center segmentation increase the likelihood of conflict.
} 


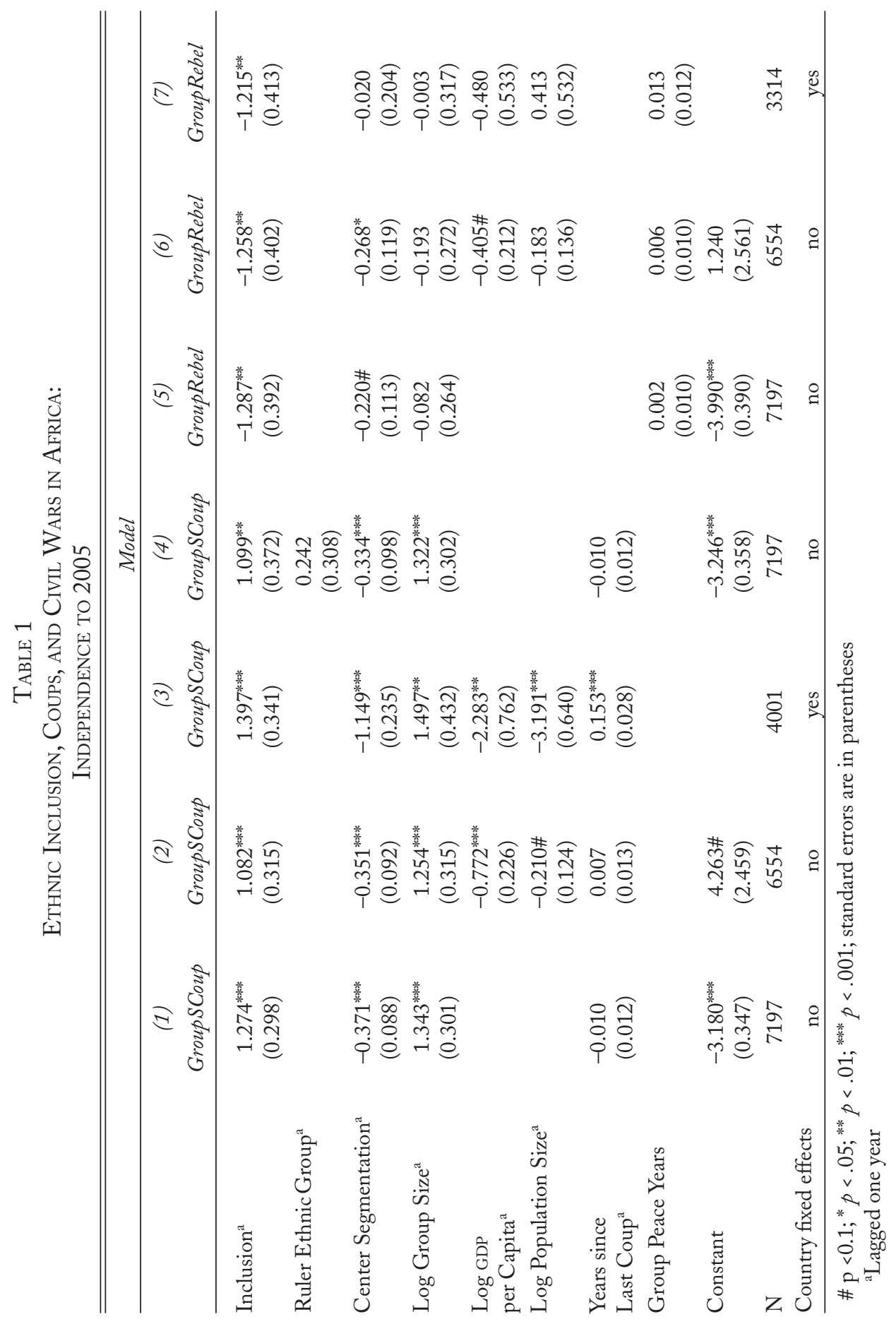


estimation but control for country fixed effects. Finally, in each of the estimations I also control for time duration: the number of years since the last coup by any group or, if the country has had no coups, since independence (Years since Coup) and the number of years since the group last participated in a civil war (Group Peace Years).

Table 1 reports the results of the regression analyses. Inclusion is highly significant in all models. Inclusion is positively associated with successful coups but negatively associated with group rebellion. The positive effect on coups is not due simply to coups coming from within the ruler's ethnic group (see model 4). As mentioned, two-thirds of groups involved in successful coups are different from the ruler's ethnic group. When intraethnic coups are executed, they occur at low levels of center segmentation, usually when the ruler's ethnic group is the only one represented in the central government. Other control variables also generate interesting results. Taking into account a group's access to power, members of a group or coalition are significantly more likely to attempt and successfully execute a coup the larger its size, the fewer the groups incorporated in the central government, and the poorer the country. Whereas the link between low income and coups has been reported before in the literature, the robust and significant effects of segmentation and group size on coups but not rebellion are novel findings. One reason for the strong association between group size and coups might be that large groups are more likely to have at least some representation in the military and therefore have greater opportunity to employ the technology of the coup d'état. Moreover, representing a large group may increase the coup plotters' bargaining power, as other factions consider whether to resist or bandwagon while the coup attempt plays out.

What accounts for the negative effect of center segmentation? Why does the inclusion of more groups in the central government reduce the likelihood that any given group will successfully execute a coup? One possible mechanism is through the dispersion of power, which reduces the threat posed by any group incorporated into the central government, while also increasing the costs and lowering the incentives for any single group to try to seize power outright. To execute a coup, the conspirators would have to take on multiple power holders or to coordinate with them. ${ }^{75}$ Moreover, as argued above, coup attempts are often preemptive acts by power holders who fear they are losing

\footnotetext{
${ }^{75}$ On the coordination problem coup plotters face, see Arriola 2009. He posits that this coordination problem accounts for the reason coups are less likely in African countries with large cabinets.
} 
their privileged position. If over time a ruler is able to maintain a more inclusive central government, it should help to allay the fears of power holders that they will be excluded in the future and reduce coup plotting. Overall, then, power dispersion and an inclusive center help to reduce uncertainty - the ruler's fear of the coup and the power holder's fear of exclusion - that is at the heart of the commitment problem and the breakdown of personalist regimes.

In models 8-13, reported in Table 2, I repeat this analysis but disaggregate access to power into the various discrete categories identified by EPR to examine how the degree of inclusion or exclusion affects the likelihood of a coup or civil war. The results suggest that relative power within the government does have important implications as to whether a group is likely to execute a successful coup. Dominant groups tend to execute more coups than other included groups. But even groups categorized as Senior Partner and Junior Partner have a significant advantage in seizing power in a coup over those excluded from the central government. Interestingly, once a group reaches Monopoly status, coups become much less likely. This might be attributable to the fact that monopoly groups often institutionalize their hegemony through a ruling political party, such as the True Whig Party in Liberia or the $\mathrm{Na}-$ tional Party in South Africa, and the party helps regulate the transfer of power within the group. Looking at rebellion, those groups considered Discriminated are more likely to rebel than are those included in the central government. Interestingly Regional Autonomy is also significant, suggesting this arrangement has not been an effective conflictreducing mechanism, as exemplified in Sudan with the breakdown of the Addis Ababa Agreement. Powerless groups are also more likely to rebel than those inside the central government, but the variable loses significance in the fixed-effects estimation (model 13), given the high concentration of these rebellious groups in Sudan and Chad.

\section{Coconspirators, Preemptive Coup Attempts, AND ETHNic Exclusion}

The previous analysis offers strong evidence to support the first hypothesis. It is unable to provide direct evidence, however, that rulers choose exclusive strategies to resolve the commitment problem that arises from elite accommodation in the shadow of the coup d'état. Perhaps the inverse effect of ethnic inclusion on coups and civil wars is merely an artifact of the legacies of colonial rule: groups historically excluded from power are more likely to rebel, whereas those that inherited the state at independence and remain at the heart of power are 


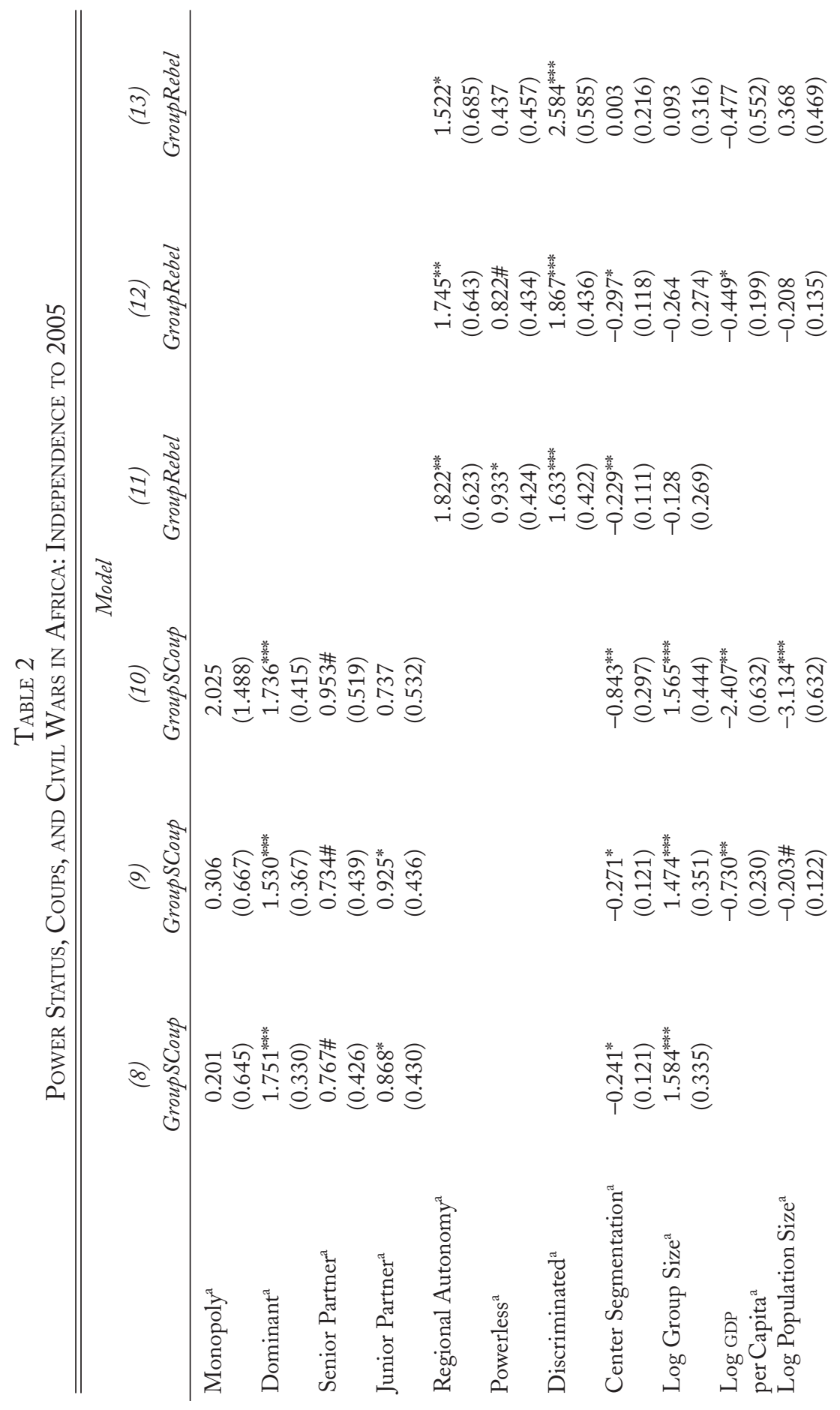




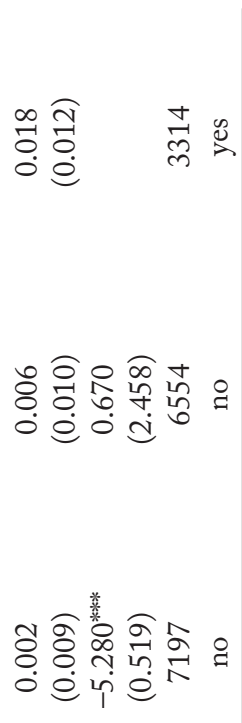

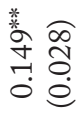

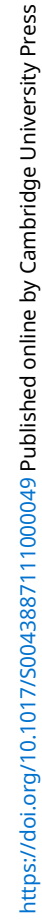

횽요

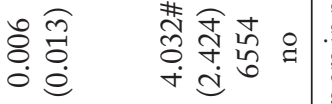

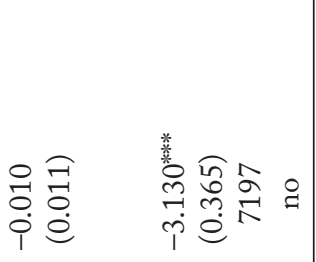

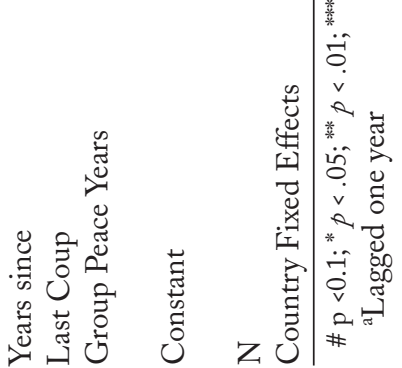


the ones who execute coups. Clearly this is part of the story, as those familiar with the histories of Mali, Mauritania, and Sudan can attest. ${ }^{76}$ In this section I aim to test whether there is also support for the more dynamic argument at the heart of this article. Is there evidence that rulers strategically use ethnic exclusion to neutralize the threat or potential threat posed by another group within the central government, though at the cost of committing to civil war?

The ideal variable to allow us to test the second hypothesis would be a measure of each group's coup-making capabilities based on their access to the security, police, and armed forces. We would expect the commitment problem to be more severe between the ruler and elites from groups with a foothold in the state's coercive apparatus vis-à-vis other elites who lack first-strike capabilities. Absent annual data on the ethnic composition of African militaries, security forces, and police, I propose that one potentially useful alternative measure, at least in those regimes that come to power by force, ${ }^{77}$ can be derived from information on coconspirators - the armed actors who led, organized, or executed the coup d'état or rebellion that deposed the old regime. Given that after seizing power these actors tend to dominate the new regime and retain their coercive capabilities, ${ }^{78}$ we could reasonably assume that coconspirators represent a powerful subsection of those in the new regime with a foothold in the state's coercive apparatus and who possess latent coup-making capabilities. In addition, considering that the recent irregular seizure of power legitimated the militarization of politics while further undermining formal institutions, we would expect coconspirators to face a particularly acute commitment problem as they try to share power. Coconspirators can come from inside or outside the eventual ruler's ethnic group, depending on who contributed to the violent seizure of power. In the May 1997 overthrow of Mobutu by the AFDL,

\footnotetext{
${ }^{76}$ The question is why this structure of power has been maintained since independence. And here is where I think this article's central argument is informative as exemplified in Sudan by the ethnoregional power struggle that tore asunder the National Islamic Front and perpetuated the political and economic dominance of riverain Arabs at the expense of other ethnic groups, especially Darfurians. See Roessler 2010.

${ }^{77}$ This accounts for the majority of regimes in postcolonial Africa. According to Goldsmith 2001, 56 percent of leadership changes (101 out of 180) in sub-Saharan Africa between 1960 and 1999 were the result of coup, war, or invasion.

${ }^{78}$ For example, after the overthrow of Idi Amin in 1979, the rebel coalition, the Uganda National Liberation Army, in effect became the new national army with the provisional government, the $\mathrm{Na}$ tional Executive Council, dominated by leaders of the UNLA. Tito Okello was chief of Defense Forces, Oyite Ojok was his deputy, and Yoweri Museveni served as minister of state for defense. In Liberia, Thomas Quiwonkpa would become commander of the army after orchestrating Samuel Doe's rise to power; in Côte d'Ivoire Northerners would occupy key positions in the Comité National de Salut Public (CNSP) after overthrowing Henri Konan Bédié and placing Robert Guéi in power.
} 
for example, we can identify three domestic groups of coconspiratorsthe Luba Shaba led by Laurent-Désiré Kabila, the Congolese Tutsi led by Deogratias Bugera, and Other Kivu Groups who were mobilized by Masasu Nindaga. ${ }^{79}$ These groups remain coded as Coconspirator as long as the ruler they put in power remains head of state (which in this case would be until 2001, when Kabila was assassinated). I code this information for all African countries represented in the EPR data set between independence and 2005 .

An even more imminent threat to a new ruler who has come to power by force are not his friends but his enemies, or anticonspirators - the members of the old guard who seek to prevent the conspirators from taking power. The new ruler recognizes that cutting a deal with his enemies and allowing them to retain a share of power in exchange for their political support would help to legitimize his irregular ascension to power and prevent a future conflict. Absent any guarantees that members of the former ruling group will not exploit such beneficence and try to reclaim political supremacy, however, the new ruler hesitates to make such a deal. Thus, we would expect the commitment problem to prevent the ruler from building a more inclusive posttransition regime and to lead to the exclusion of anticonspirators. To test this hypothesis I construct a variable Irregular Replacement that indicates whether in the current or previous two years a member of a given group was the ruler of the country but was removed from power in a coup or rebellion or by some other forcible means by members of a rival ethnic group.

\section{OPERATIONALIZING THE “EXCLUDE” VARIABLE}

Before describing the regression results, it is important to discuss how the dependent variable, Exclude, is coded. The dependent variable is intended to capture the onset of a group's exclusion from the central government. The most straightforward way to measure this is to use the EPR data to determine whether a group that had been represented in the central government in the previous year (that is, coded as Monopoly, Dominant, Senior Partner, or Junior Partner) is excluded in the current year (that is, coded as Powerless or Discriminated)..$^{80} \mathrm{I}$ label this Exclude Basic. But a lot can happen in the course of a year. Members of excluded groups can contribute to the overthrow of a dictator, such as members of the Nyankole and Banyarwanda did in the overthrow of

\footnotetext{
${ }^{79}$ The ethnic categories correspond to those in the EPR data set.

${ }^{80} \mathrm{As} \mathrm{I} \mathrm{am} \mathrm{interested} \mathrm{in} \mathrm{purges} \mathrm{or} \mathrm{forcible} \mathrm{exclusion} \mathrm{from} \mathrm{the} \mathrm{central} \mathrm{government,} \mathrm{I} \mathrm{do} \mathrm{not} \mathrm{consider}$ changes to or from Regional Autonomy as an incidence of Exclude.
} 
Idi Amin in Uganda in 1979, and then find their group represented at the top of the new transitional government, in this case by Yoweri $\mathrm{Mu}-$ seveni and as part of the National Executive Council, only to lose out in the subsequent struggle for power, leading to their exclusion from power. ${ }^{81}$ Thus, though the EPR considers these groups consistently excluded from power throughout, in fact for a brief important period, often less than year, they were at the heart of the new regime. Had history played out differently, with them winning in the power struggle, they would have been considered included throughout. To capture these more fluid intrayear changes, I also construct a second exclusion variable, Exclude Dynamic, which indicates whether a group is excluded from the central government in the current year but was included in the central government in the previous year or played a critical role in the seizure of power in the previous year (and thus was coded as a Coconspirator). Exclude Dynamic picks up five additional cases of excluded groups missed by Exclude Basic. ${ }^{82}$

\section{REGRESSION ANALYSIS AND DISCUSSION OF RESULTS}

To estimate the determinants of ethnic exclusion, I run several models looking only at groups included in the central government in the previous year or, for models using Exclude Dynamic, at groups that contributed to the incumbent's seizure of power in the previous year. ${ }^{83}$ Thus, the regressions estimate the likelihood a group that was in power in the previous year is excluded in the current year. Models 14 and 15 in Table 3 use Exclude Basic as the dependent variable, and models 16 and 17 use Exclude Dynamic. I also include a variable, Ruler Ethnic Group, that indicates whether the incumbent is a member of the group. This is

${ }^{81}$ The same is true for Northerners in Côte d'Ivoire in 2000. Langer notes that the first Guéi cabinet was the most inclusive in a generation, including for Northerners, who filled top seats in the new regime. General Lassana Palenfo, for example, was second-in-command and security minister. Langer writes: "It is interesting to note that the inter-ethnic political inequalities of the January 2000 government as measured by the Political Inequality Measure (PIM) was the lowest of any government in the period from 1980 to 2003. The same observation holds regarding ethnic representation within the inner circle of political power." This would begin to change, however, with Guéi's first cabinet reshuffle in May 2000, his support for the concept of l'Ivoirite, and his "purge [of] the military forces" that excluded "a significant number of officers and soldiers with a northern background." Langer 2004. Thus, though EPR codes Northerners as excluded throughout 2000, in fact, after several of their members in the military helped put Guéi in power, they were included in the heart of the new government for several months.

${ }^{82}$ Ibo of Nigeria in 1966; Baganda and South-Westerners (Ankole, Banyoro, Toro, Banyarwanda) of Uganda in 1980; Gio of Liberia in 1980; and Northerners (Mande and Voltaic/Gur) in Côte d'Ivoire in 2000.

${ }^{83}$ The models cover only groups included in the central government in the current or previous year and those groups that contributed to the incumbent's seizure of power in the current or previous year, since those that remain excluded have no possibility of being purged. 


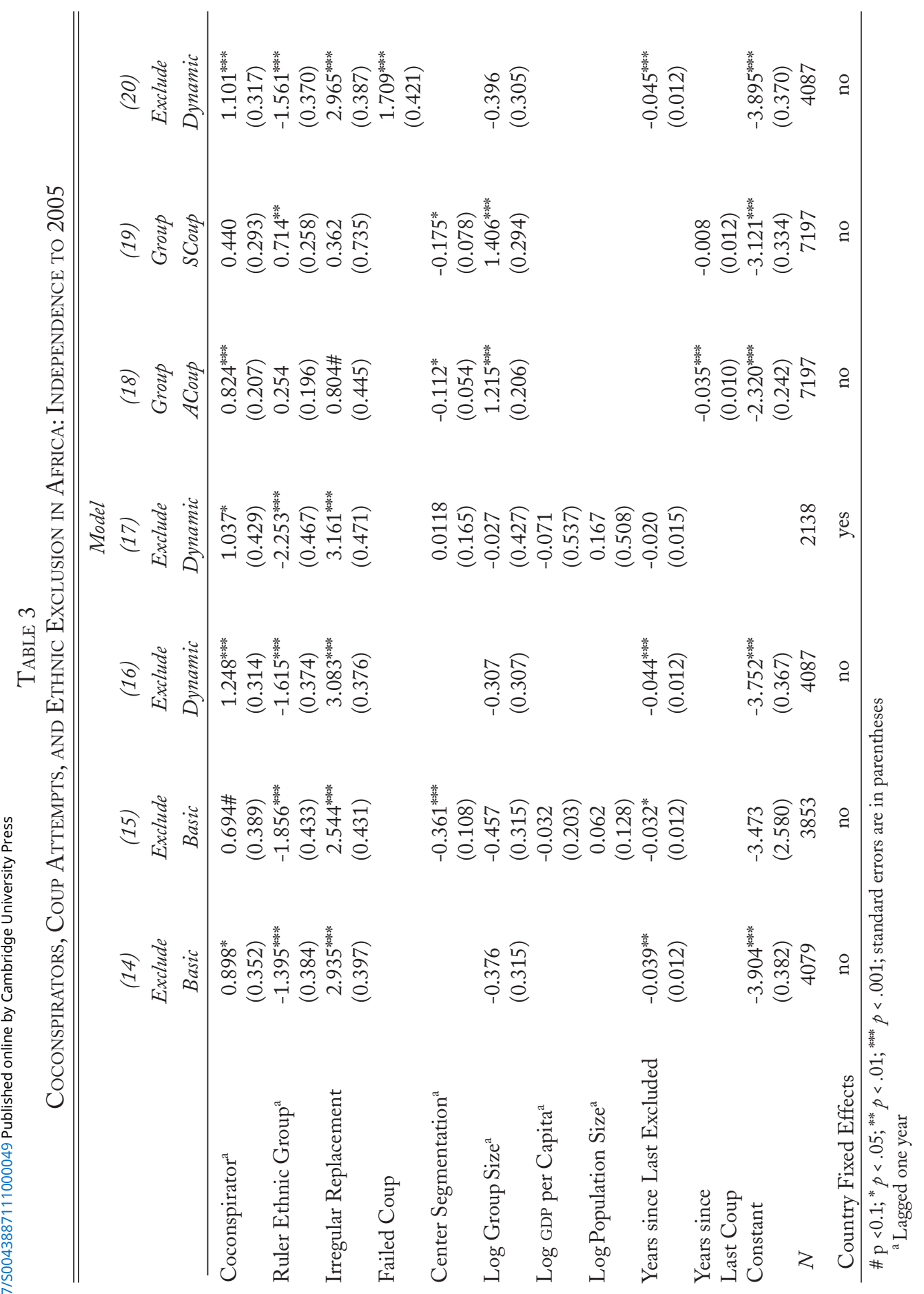


an important control variable to include, given the importance of ethnic support bases for incumbents in Africa and the constraints rulers face in barring or purging their own coethnics from power. I also include the group-level and country-level variables incorporated within the previous models.

The results confirm that the ruler's forcible overthrow in the current or previous year (Irregular Replacement) increases the risk that the former incumbent group will be excluded from power. While this may seem like a trivial substantive finding, it is theoretically important, as it is consistent with the central argument about the challenges of forging political bargains in the face of the commitment problem, which we would expect to be particularly acute during an irregular regime transition. A more novel finding - and one that further points to the importance of the commitment problem in causing ethnic exclusion-is that rulers are more likely to exclude not only their enemies but also the very friends and allies who put them in power. When controlling for Ruler Ethnic Group (REG), Coconspirator is significant across all models ${ }^{84}$ and substantively important, as illustrated in Figure $6 .{ }^{85}$ Coconspirators from outside the ruler's ethnic group are three-and-a-half times more likely than other power holders to be purged from the central government. Interestingly, and contrary to economic arguments that predict ethnic exclusion is more likely in low-income countries due to increased competition over distribution of state spoils, income level has no effect on the likelihood that a group in the central government will be purged.

I contend that the commitment problem increases the likelihood that coconspirators will become locked in an internal security dilemma and that it is this dynamic process that drives rulers to resort to violence to exclude their former allies. Rulers employ ethnic exclusion in a desperate final bid to protect themselves from what they view is an imminent existential threat. For their part, the coconspirators, having become increasingly fearful of such an eventuality, seek to oust the ruling clique to preempt their exclusion from power. But such retrieval coups often fail. To test this element of the argument, models 18 and 19 in Table 3 examine the likelihood that coconspirators will gamble to

\footnotetext{
${ }^{84} \mathrm{As}$ is evident in comparing models 14 and 16, Coconspirator is a more robust predictor of Exclude Dynamic than Exclude Basic. This suggests the commitment problem can arise very quickly in irregular regimes and it is important not to overlook those first decisive months in power.

${ }^{85}$ As coconspirators can come from inside or outside the ruler's ethnic group, we control for Ruler Ethnic Group to isolate the effect coconspirators outside the ruler's ethnic group have on the likelihood of ethnic exclusion. If I control for Ruler EPR Category instead of Ruler Ethnic Group, the results are similar.
} 


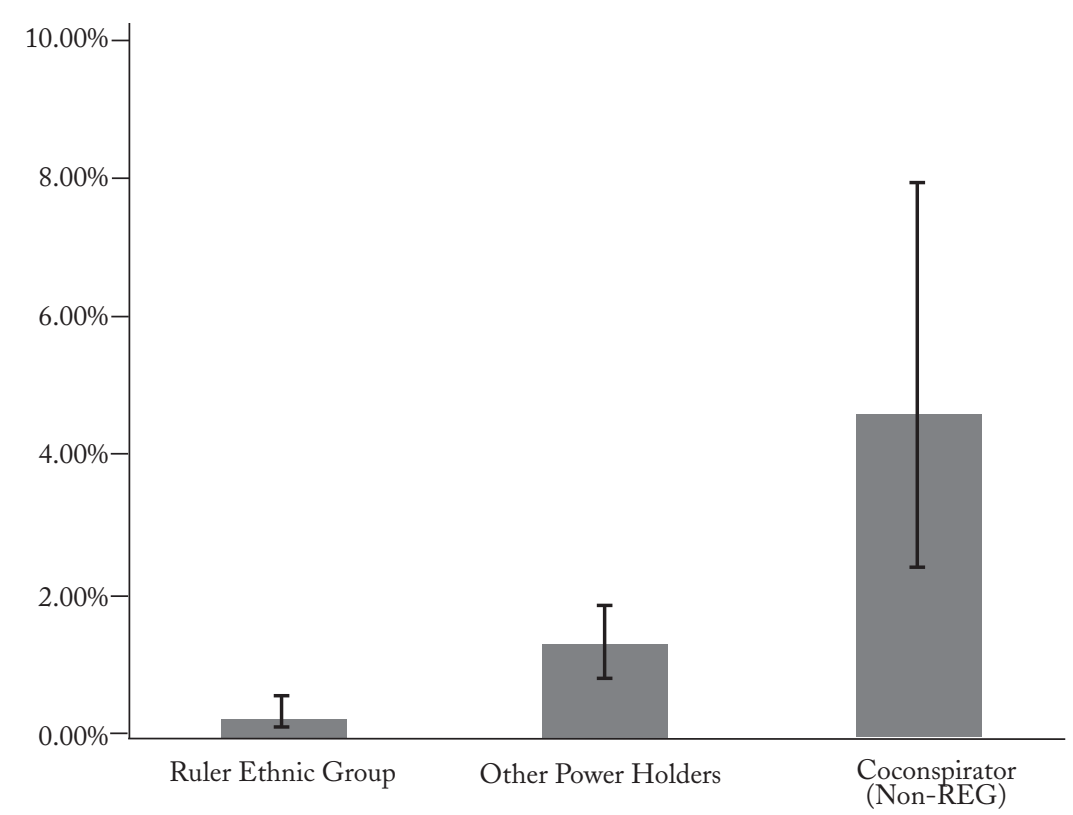

FiguRe 6

Predicted Probability of Ethnic Exclusion across Different Government Power Holders in Africa, Independence to 2005ª

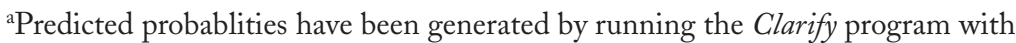
model 16 in Table 3. Dependent variable is Exclude Dynamic. Irregular Replacement has been set at 0 and Center Segmentation, Log Group Size, and Years since Last Exclusion are set at their mean. The Coconspirator and Ruler Ethnic Group variables were manipulated to create the three categories. "Ruler Ethnic Group" bar was created by setting Ruler Ethnic Group at 1 and Coconspirator at 0; "Other Group in Power" bar was created by setting Ruler Ethnic Group at 0 and Coconspirator at 0; "Coconspirator" bar was created by setting Ruler Ethnic Group at 0 and Coconspirator at 1.

usurp power and whether they will be successful. Consistent with the article's central argument, coconspirators are significantly more likely than other groups to try to topple the incumbent in a coup d'état but with a very low success rate. ${ }^{86}$ These results are illustrated graphically in Figure 7. What is ironic about the coconspirators' inability to reclaim power as the internal rivalry plays out is they were often the ones who

\footnotetext{
${ }^{86}$ Of the twenty-two coup attempts by non-REG coconspirators, only six were successful, almost half the normal coup rate by groups included in power and even lower than the rate for excluded groups illustrated in Figure 5. Consistent with the argument that these are preemptive coup attempts, more than 60 percent occurred while the coconspirators were still included in the central government.
} 


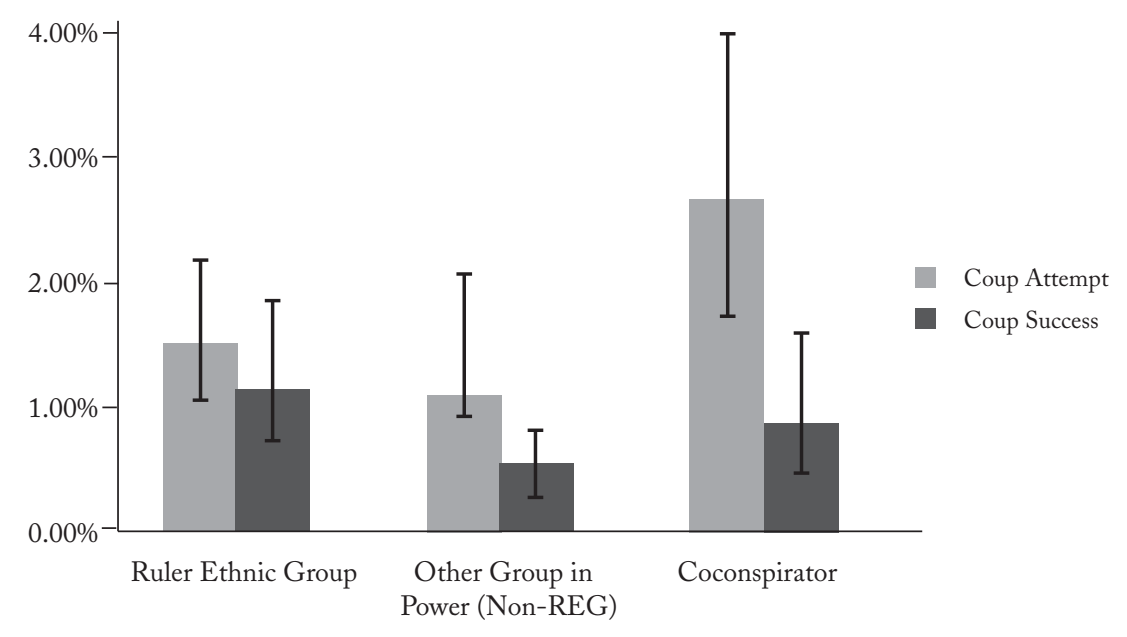

FIGURE 7

\author{
Predicted Probability of Coup Attempts and Coups \\ across Different Government Power Holders in Africa, \\ INDEPENDENCE TO 2005
}

a Predicted probablities have been generated by running the Clarify program with models 18 and 19 in Table 3. Irregular Replacement has been set at 0 and Center Segmentation, Log Group Size, and Years since Last Coup are set at their mean. The Coconspirator and Ruler Ethnic Group variables were manipulated as described in Figure 6 to create the three power holder categories.

recruited the incumbent in the first place. Kérékou in Benin, Bashir in Sudan, Kabila in DRC, and Guéi in Côte d'Ivoire were all leaders by default - ranking military or rebel figures who were brought in by the conspirators for lack of a better alternative to serve as a figurehead. This suggests the emergence of a sort of incumbency advantage for these "default" rulers who are able to exploit their discretionary power to coup-proof their regimes, even as such techniques provoke violence and undermine power sharing.

FAILED COUPS AND ETHNIC EXCLUSION

The analysis raises the question whether the article's central argument applies beyond Africa's irregular regimes. In other words, does the commitment problem also arise between the ruler and other power 
holders who possess a foothold in the state's coercive apparatus, but who are not coconspirators or anticonspirators? Again in the absence of systematic data on ethnic composition of the military, it is difficult to test this exogenously. One revealing endogenous implication, however, would be if we see evidence of a strong association between failed coups and ethnic exclusion, controlling for Coconspirator. Such a finding may suggest the development of an internal security dilemma between the ruler and other power holders with recourse to violence that culminates in violent rupture as both sides try to eliminate the other. It would also provide additional evidence to support the claim that rulers employ the costly strategy of ethnic exclusion to nullify future internal threats. Having nearly been deposed in a coup, the incumbent employs systematic exclusion to quash the rival's capability to organize a subsequent internal challenge. To test this, in model $20 \mathrm{I}$ add the variable Group Failed Coup, which measures whether members of a given group attempted a failed coup in the current or previous year. The results reported in Table 3 reveal a strong association between failed coups and ethnic exclusion, controlling for whether the group perpetrating the coup was a coconspirator.

\section{A New Model of Civil War in Africa: From Conspirators to Belligerents}

Overall this article's central argument and analysis challenge the structuralist interpretation of civil war in Africa. It offers instead a more dynamic theoretical explanation that views a significant subset of civil wars as emanating from struggles for power within central governments. One of the key implications of this argument is that conspirators who are allies today become enemies at war in the future. To test this overall argument, I rerun the rebellion regressions (see models 5-7 in Table 1) adding Coconspirator, Ruler Ethnic Group, and Irregular Replacement to the estimations. The results are displayed in Table 4. When controlling for Ruler Ethnic Group, which has a significant negative effect on likelihood of group rebellion, Coconspirator and Irregular Replacement are highly significant and robust. (See models 21 and 22.) Model 25 illustrates that most coconspirators who rebel against their former patron are more likely to do so in the first three years of being purged from the central government. As illustrated in Figure 8, being a non-REG coconspirator and excluded from the central government increases the risk of group rebellion in a given year to nearly 5 percent versus less than 1 percent for other excluded groups. Group rebellion risk jumps to over 15 percent when also taking into consideration whether the non-REG 
TABLE 4

Coconspirators and Rebellion in Africa: IndePendence to 2005

\begin{tabular}{|c|c|c|c|c|c|}
\hline & $\begin{array}{l}\text { (21) } \\
\text { GroupRebel }\end{array}$ & $\begin{array}{c}\text { (22) } \\
\text { GroupRebel }\end{array}$ & $\begin{array}{c}\text { Model } \\
\text { (23) } \\
\text { GroupRebel }\end{array}$ & $\begin{array}{c}\text { (24) } \\
\text { GroupRebel }\end{array}$ & $\begin{array}{c}\text { (25) } \\
\text { GroupRebel }\end{array}$ \\
\hline Coconspirator $^{\mathrm{a}}$ & $\begin{array}{l}1.627^{* * *} \\
(0.405)\end{array}$ & $\begin{array}{l}1.180^{* *} \\
(0.451)\end{array}$ & $\begin{array}{l}1.435^{* * *} \\
(0.416)\end{array}$ & $\begin{array}{l}1.379^{* *} \\
(0.494)\end{array}$ & $\begin{array}{c}0.862 \# \\
(0.490)\end{array}$ \\
\hline $\begin{array}{l}\text { Ruler Ethnic } \\
\text { Group }^{\mathrm{a}}\end{array}$ & $\begin{array}{r}-1.648^{*} \\
(0.722)\end{array}$ & $\begin{array}{r}-1.475^{*} \\
(0.731)\end{array}$ & $\begin{array}{r}-1.546^{*} \\
(0.423)\end{array}$ & $\begin{array}{r}-1.800^{*} \\
(0.761)\end{array}$ & $\begin{array}{c}-1.390 \# \\
(0.727)\end{array}$ \\
\hline Inclusion $^{\mathrm{a}}$ & $\begin{array}{l}-1.174^{*} \\
(0.461)\end{array}$ & $\begin{array}{r}-1.083^{*} \\
(0.473)\end{array}$ & $\begin{array}{r}-1.161^{*} \\
(0.461)\end{array}$ & $\begin{array}{r}-1.163^{*} \\
(0.505)\end{array}$ & $\begin{array}{c}-0.865 \# \\
(0.462)\end{array}$ \\
\hline $\begin{array}{l}\text { Recently Excluded } \\
\text { Coconspirator }\end{array}$ & & & & & $\begin{array}{l}2.151^{* * * *} \\
(0.558)\end{array}$ \\
\hline $\begin{array}{l}\text { Irregular } \\
\quad \text { Replacement }\end{array}$ & $\begin{array}{l}2.538^{* * * *} \\
(0.563)\end{array}$ & $\begin{array}{l}2.382^{* * * *} \\
(0.567)\end{array}$ & $\begin{array}{l}2.469^{\text {**** }} \\
(0.565)\end{array}$ & $\begin{array}{l}2.317^{* * * *} \\
(0.603)\end{array}$ & $\begin{array}{l}1.761^{*} \\
(0.645)\end{array}$ \\
\hline Group Failed coup & & & $\begin{array}{r}1.264^{*} \\
(0.551)\end{array}$ & $\begin{array}{r}1.141^{*} \\
(0.551)\end{array}$ & \\
\hline $\begin{array}{l}\text { Center } \\
\text { Segmentation }^{\mathrm{a}}\end{array}$ & $\begin{array}{c}-0.231 \# \\
(0.125)\end{array}$ & $\begin{array}{r}-0.289^{*} \\
(0.131)\end{array}$ & $\begin{array}{c}-0.234 \# \\
(0.125)\end{array}$ & $\begin{array}{c}0.017 \\
(0.199)\end{array}$ & $\begin{array}{r}-0.285^{*} \\
(0.129)\end{array}$ \\
\hline Log Group Size ${ }^{a}$ & $\begin{array}{c}-0.230 \\
(0.268)\end{array}$ & $\begin{array}{c}-0.272 \\
(0.278)\end{array}$ & $\begin{array}{l}-0.275 \\
(0.266)\end{array}$ & $\begin{array}{c}0.019 \\
(0.315)\end{array}$ & $\begin{array}{l}-0.213 \\
(0.266)\end{array}$ \\
\hline $\begin{array}{l}\text { Log GDP per } \\
\text { Capita }^{\mathrm{a}}\end{array}$ & & $\begin{array}{l}-0.337 \\
(0.218)\end{array}$ & & & \\
\hline $\begin{array}{l}\text { Log Population } \\
\text { Size }^{1}\end{array}$ & & $\begin{array}{l}-0.129 \\
(0.135)\end{array}$ & & & \\
\hline Group Peace Years & $\begin{array}{l}-0.003 \\
(0.010)\end{array}$ & $\begin{array}{c}0.001 \\
(0.010)\end{array}$ & $\begin{array}{c}-0.003 \\
(0.010)\end{array}$ & $\begin{array}{c}0.012 \\
(0.010)\end{array}$ & $\begin{array}{r}0.000 \\
(0.10)\end{array}$ \\
\hline Constant & $\begin{array}{l}-4.188^{* * * *} \\
(0.412)\end{array}$ & $\begin{array}{l}-0.105 \\
(2.629)\end{array}$ & $\begin{array}{l}-4.280^{* * * *} \\
(0.415)\end{array}$ & & $\begin{array}{l}-4.204^{* * *} \\
(0.412)\end{array}$ \\
\hline$N$ & 7197 & 6554 & 7197 & 4034 & 7197 \\
\hline $\begin{array}{l}\text { Country Fixed } \\
\text { Effects }\end{array}$ & no & no & no & yes & no \\
\hline
\end{tabular}

coconspirator was recently purged from power. A final result of interest: the significance of Group Failed Coup in models 23 and 24 in Table 4 suggests, moreover, that this pathway is not necessarily limited to conflict between the ruler and coconspirators and anticonspirators but that it may also involve other power holders who possess coercive capabilities. 


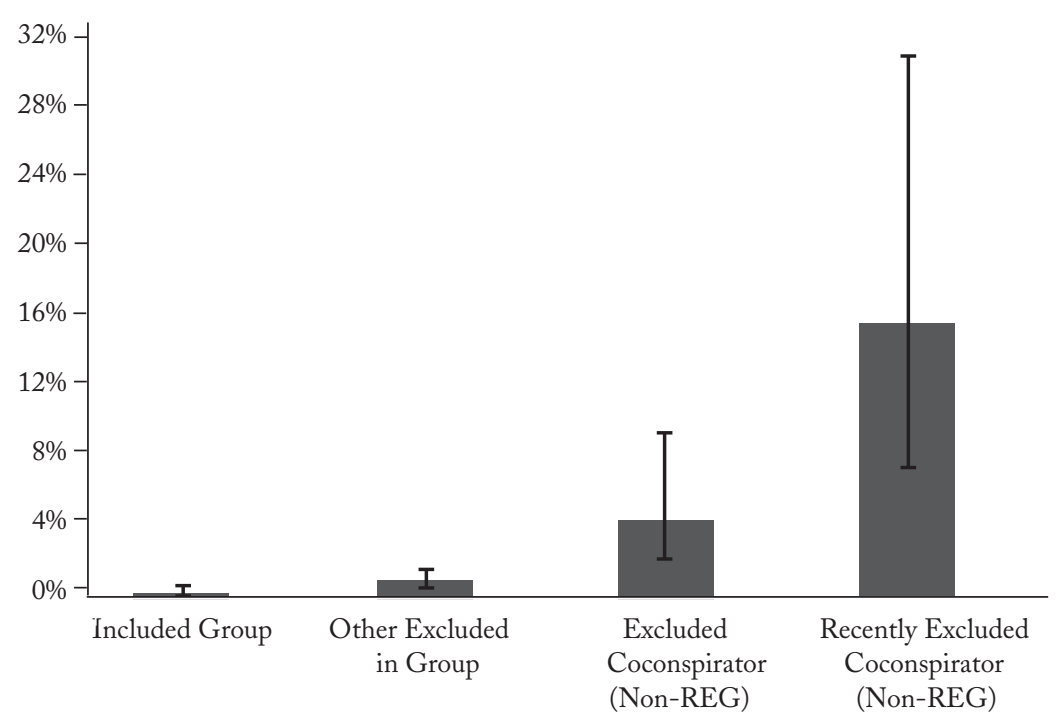

FigURE 8

Predicted Probability of Group Rebellion in Africa, INDEPENDENCE TO $2005^{\mathrm{a}}$

a Predicted probabilities for "Included Group," "Other Excluded Group," and "Excluded Coconspirator" have been generated by running the Clarify program with model 22 in Table 4. "Recently Excluded Coconspirator" is from model 26 in Table 4. Dependent variable is Group Rebel. For each, Irregular Replacement has been set at 0 and Center Segmentation, Log Group Size, and Years since Last Group Rebellion are set at their mean. "Included Group" bar was created by setting Inclusion at 1 and Coconspirator at 0; "Other Excluded Group" bar was created by setting Inclusion at 0 and Coconspirator at 0; "Excluded Coconspirator" bar was created by setting Inclusion at 0 and Coconspirator at 1 . "Recently Excluded Coconspirator" bar was created by setting Inclusion at 0, Coconspirator at 1, and Recently Excluded Coconspirator at 1.

\section{Conclusion}

This article seeks to explain why rulers in Africa adopt the costly strategy of ethnic exclusion. It proposes that such a strategy resolves the commitment problem that arises as elites with first-strike capabilities try to share power but become locked in an internal security dilemma. Consistent with this argument, I demonstrate that rulers are more likely to exclude groups who pose a credible threat to their political survival, including the anticonspirators who opposed their seizure of 
power but even their coconspirators, who often end up being as formidable an adversary as those in the ancien régime. I demonstrate that coconspirators who are not members of the ruler's ethnic group are significantly more likely than other power holders to attempt coups, though with a poor rate of success. This suggests that the incumbent's coup-proofing techniques, while destabilizing, often prove effective. The cost of purging one's former allies from the central government, however, is an increased likelihood of civil war. After being purged from the central government, non-REG coconspirators are five times more likely to rebel in a given year than other excluded groups. Most of these rebellions occur in the first few years after a violent rupture, as the incumbent's exclusive strategy forfeits societal and territorial control and as the former coconspirators switch technologies of resistance from coups to insurgency.

Overall this analysis suggests an alternative explanation as to why there has been the concentration of civil wars in the rural periphery of poor, postcolonial states. It argues that peripheral civil wars are more deeply connected to the center than is often recognized in the extant literature; elite bargaining and the incumbent's strategies of political survival can be as significant as drivers of large-scale political violence as are underlying structural conditions or bad neighborhoods. The article's central argument also sheds new light on the conflict trap and why irregular seizures of power are found to increase the risk of civil war. ${ }^{87}$ Substantively the logic informs the outbreak of some of Africa's most devastating civil wars, including, the 1972 violence in Burundi; the first rebellion in Somalia in the early 1980s; the post-Idi Amin civil war in Uganda; Zimbabwe's postindependence war in Matabeleland; Déby's rebellion against Habré in Chad in 1989; the Liberian civil war in 1989; the war in Guinea-Bissau in 1998; the start of "Africa's Great War" in August 1998 in the Democratic Republic of Congo; Bozize's rebellion in Central African Republic in late 2002; the 2002 conflict in Côte d'Ivoire; and the Darfur rebellion in Sudan in 2002. In each of these cases we can locate the antebellum elite bargains that were in place and, if maintained, could have prevented civil war. Moreover, we can identify the process by which the commitment problem undermines these bargains, leading to violent exclusion and conflict escalation.

The analysis raises many questions for future research. First, what are the implications if coups and violent personal rule become less

\footnotetext{
${ }^{87}$ Gleditsch and Ruggeri 2010. Gleditsch and Ruggeri attribute the association between irregular regime change and civil war to the opportunity structure for rebel mobilization, rather than to the strategic interactions of elites within the regime.
} 
widespread in sub-Saharan Africa? While irregular seizures of power and personal rule still occur too frequently, leading to the precise dynamics we would predict, there has been a discernible change in the nature of political transitions across many African countries since the end of the cold war, as illustrated in Figure $3{ }^{88}$ How does the institutionalization of political power and growing anticoup measures by the African Union and international donors affect elite accommodation, mitigate the commitment problem, and account for the post-cold war decline in civil war? Moreover, how applicable is this civil war pathway to other weak states around the world? Or does the unusual combination of coup proneness, elite accommodation, ethnic brokerage, and geographically concentrated ethnic groups make it unique to Africa's personalist regimes?

\section{Appendix 1 \\ VARIABLE Definition List}

\section{Center Segmentation}

The number of groups represented in the central government. Source: EPR data set.

\section{COCONSPIRATOR}

A dummy variable indicating if members of a given ethnic group led, organized, or played another prominent role in the violent seizure of power by the current incumbent. For a list of coconspirators, see Roessler 2011, Table II.

\section{Ethnic Dominance}

A dummy variable indicating if for a given country-year any group is coded as Dominant. Source: EPR data set.

\section{ETHNOCRACY}

A dummy variable indicating if for a given country-year any group is coded as Monopoly. Source: EPR data set.

ExClude BASIC

A dummy variable indicating if for a given country-year a group is coded as Discriminated or Powerless but in the previous year was coded as Monopoly, Dominant, Senior Partner, or Junior Partner. Source: EPR data set.

${ }^{88}$ See also Posner and Young 2007. 
EXClude DyNAMic

A dummy variable indicating if for a given country-year a group is coded as Discriminated or Powerless but in the previous year was coded as Monopoly, Dominant, Senior Partner, or Junior Partner or coded as Coconspirator. Sources: EPR data set and author codings.

\section{GroupAcoup}

A dummy variable indicating whether members of a given ethnic group executed a successful or failed coup d'état in the current year. Source: McGowan 2003 for list of coups. Ethnicity of conspirators coded by author. For coup leaders and their ethnicities, see Roessler 2011, Table II.

\section{GroupFCOUP}

A dummy variable indicating whether members of a given ethnic group attempted a failed coup d'état in the current year. Source: McGowan 2003 for list of coups. Ethnicity of conspirators coded by author. For coup leaders and their ethnicities, see Roessler 2011, Table II.

\section{Group Failed Coup}

A dummy variable indicationg whether members of a given ethnic group executed a failed coup d'état in the current or previous year. Source: McGowan 2003 for list of coups. Ethnicity of conspirators coded by author. For coup leaders and their ethnicities, see Roessler 2011, Table II.

\section{Group Peace Years}

Number of years since group was last involved in civil war. Sources: Fearon and Laitin 2003; Sambanis 2004; Lacina and Gleditsch 2005; and author's codings.

GroupRebel

A dummy variable indicating the onset of large-scale violence between members of a given ethnic group and the central government. See footnote 71 for how civil war onset at the group level is coded. Source: coded by author. For a list of rebellion onsets and the ethnicity of the rebels, see Roessler 2011, Table III.

\section{GroupSCOUP}

A dummy variable indicating whether members of a given ethnic group executed a successful coup d'état in the current year. Source: McGowan 2003 for list of coups. Ethnicity coded by author. For coup leaders and their ethnicities, see Roessler 2011, Table II. 


\section{INCLUSION}

A dummy variable indicating an ethnic group's access to or exclusion from the central government. Scores are derived from the EPR's categorical variable on access to power. Groups coded as Monopoly, Dominant, Senior Partner, or Junior Partner on the EPR index in a given year are scored 1. Groups coded as Regional Autonomy, Powerless, or Discriminated are scored 0. Source: EPR data set.

Inclusive, Power SHARING

A dummy variable indicating if for a given country-year there are no groups excluded from access to the central government (i.e., coded as a 0 on Inclusion) and no group is Monopoly or Dominant. Source: EPR data set.

\section{IRREGULAR REPLACEMENT}

A dummy variable indicating if for a given group (1) the ruler of the country was a member of the group in the current or previous two years and (2) during that time the ruler was removed from power in a coup or rebellion or through other forcible means by members of a rival ethnic group. See Roessler 2011, Table I.

\section{Log Group Size:}

Natural log of the group's proportion of the population. Source: EPR data set.

\section{Log INCOME}

Natural log of the country's gross domestic product per capita (constant U.S.\$2000). Source: World Bank 2009.

Log Population

Natural log of the country's total population. Source: World Bank 2009. Power Sharing but Some Exclusion

A dummy variable indicating if for a given country-year no group is Monopoly or Dominant but at least one or more politically relevant groups is excluded. Source: EPR data set.

Recently Excluded Coconspirator

A dummy variable indicating if a group is coded as a Coconspirator and coded as Exclude Dynamic in previous three years. 


\section{Ruler Ethnic Group (REG)}

A dummy variable indicating if the ruler of the country is a member of a given ethnic group. Source for ethnic group codings: Fearon 2003. Sources for ruler's ethnic group: Fearon, Kasara, and Laitin 2007; and author's codings.

YEARS SINCE COUP

Number of years since any group in the country successfully executed a coup. Sources: McGowan 2003; and author's codings.

YEARS SINCE LAST EXCLUDED

Number of years since group was last excluded from central government. Source: EPR data set.

ApPENDix 2

Descriptive Statistics

\begin{tabular}{lcccc}
\hline \hline \multicolumn{1}{c}{ Variable } & Mean & $\begin{array}{c}\text { Standard } \\
\text { Deviation }\end{array}$ & Minimum & Maximum \\
\hline Inclusion & 0.570 & 0.496 & 0 & 1 \\
Ruler Ethnic Group & 0.200 & 0.399 & 0 & 1 \\
Monopoly & 0.030 & 0.159 & 0 & 1 \\
Dominant & 0.050 & 0.216 & 0 & 1 \\
Senior Partner & 0.150 & 0.361 & 0 & 1 \\
Junior Partner & 0.340 & 0.473 & 0 & 1 \\
Regional Autonomy & 0.030 & 0.157 & 0 & 1 \\
Powerless & 0.270 & 0.447 & 0 & 1 \\
Discriminated & 0.130 & 0.340 & 0 & 1 \\
GroupSCoup & 0.011 & 0.102 & 0 & 1 \\
GroupACoup & 0.021 & 0.142 & 0 & 1 \\
GroupRebel & 0.008 & 0.088 & 0 & 1 \\
Log Group Size & -0.991 & 0.477 & -4.61 & -0.010 \\
Center Segmentation & 2.960 & 1.870 & 1 & 7 \\
Log Income & 5.929 & 0.848 & 4.39 & 9.06 \\
Log Population Size & 15.946 & 1.179 & 12.94 & 18.77 \\
Coconspirator & 0.104 & 0.306 & 0 & 1 \\
Recently Excluded Coconspirator & 0.075 & 0.086 & 0 & 1 \\
Irregular Replacement & 0.005 & 0.066 & 0 & 1 \\
Exclude Basic & 0.009 & 0.092 & 0 & 1 \\
Exclude Dynamic & 0.009 & 0.096 & 0 & 1 \\
Group Peace Years & 20.509 & 14.009 & 0 & 60 \\
Years since Last Coup & 15.391 & 11.932 & 0 & 60 \\
Years since Excluded & 10.874 & 13.647 & 0 & 60 \\
\hline
\end{tabular}




\section{REFERENCES}

Africa Confidential. 1989. “Chad: The Warlords Return.” 30, no. 14 (July 7): 5.

Alexander, Jocelyn. 1998. "Dissident Perspectives on Zimbabwe's Post Independence War." Africa 68, no. 2: 151-82.

Amnesty International. 2001. "Chad: The Habre Legacy." At http://www .amnesty.org/en/library/info/AFR20/004/2001/en, accessed June 15, 2009.

Arriola, Leonardo R. 2009. "Patronage and Political Stability in Africa." Comparative Political Studies 42, no. 10 (October): 1339-62.

Azam, Jean-Paul. 2004. "The Redistributive State and Conflicts in Africa." Journal of Peace Research 38, no. 4 (July): 429-44.

Bayart, Jean-François. 1993. The State in Africa: The Politics of the Belly. London: Longman Publishing Group.

BBC Summary of World Broadcasts. 1989. "Chad Habre Accuses Sudan of Complicity in April Coup Plot.” May 12.

Blattman, Christopher, and Edward Miguel. 2010. "Civil War." Journal of Economic Literature 48, no. 1 (March): 3-57.

Bodea, Cristina, and Ibrahim A. Elbadawi. 2007. "Riots, Coups and Civil War: Revisiting the Greed and Grievance Debate." World Bank Policy Research Working Paper no. 4397. Washington, D.C.: World Bank.

Boone, Catherine. 1992. Merchant Capital and the Roots of State Power in Senegal, 1930-1985. New York: Cambridge University Press.

Burr, J. Millard, and Robert O. Collins. 1999. Africa's Thirty Years War: Libya, Chad and the Sudan, 1963-1993. Boulder, Colo.: Westview Press.

Cederman, Lars-Erik, Andreas Wimmer, and Brian Min. 2010. "Why Do Ethnic Groups Rebel? New Data and Analysis." World Politics 62, no. 1 (January): 87-119.

Clapham, Christopher. 1982. "Clientelism and the State." In Christopher Clapham, ed., Private Patronage and Public Power: Political Clientelism in the Modern State. New York: St. Martin's Press.

Collier, Paul, and Anke Hoeffler. 2004. "Greed and Grievance in Civil War." $O x-$ ford Economic Papers 56, no. 4 (October): 563-95.

Decalo, Samuel. 1990. Coups and Army Rule in Africa, 2nd ed. New Haven, Conn.: Yale University Press.

- 1995. Historical Dictionary of Benin. Lanham, Md.: Scarecrow Press. Press.

Dickie, John, and Alan Rake. 1973. Who's Who in Africa: The Political, Military and Business Leaders of Africa. London: African Development.

Ellis, Stephen. 1999. The Mask of Anarchy: The Destruction of Liberia and the Religious Dimension of an African Civil War. London: C. Hurst and Co.

Enloe, Cynthia H. 1980. Ethnic Soldiers: State Security in Divided Societies. Athens, Ga.: University of Georgia Press.

Fearon, James D. 2003. "Ethnic and Cultural Diversity by Country." Journal of Economic Growth 8, no. 2 (June): 195-222.

Fearon, James D. 2008. "Economic Development, Insurgency, and Civil War." In Elhanan Helpman, ed., Institutions and Economic Performance. Cambridge: Harvard University Press.

Fearon, James D., and David D. Laitin. 1996. "Explaining Interethnic Cooperation." American Political Science Review 90, no. 4 (December): 715-35. 
. 2003. "Ethnicity, Insurgency, and Civil War." American Political Science Review 97, no. 1 (February): 75-90.

-2011. "Sons of the Soil, Migrants, and Civil War." World Development 39, no. 2 (February): 199-211.

Forrest, Joshua B. 1987. "Guinea-Bissau since Independence: A Decade of Domestic Power Struggles." Journal of Modern African Studies 25, no. 1 (March): 95-116.

- 2003. "Democratization in a Divided Urban Political Culture: GuineaBissau." In Leonardo Villalón and Peter VonDoepp, eds., The Fate of Africa's Democratic Experiments: Elites and Institutions. Bloomington: Indiana University Press.

Gleditsch, Kristian S., and Andrea Ruggeri. 2010. "Political Opportunity Structures, Democracy, and Civil War." Journal of Peace Research 47, no. 3 (May): 299-310.

Goldsmith, Arthur. 2001. "Risk, Rule and Reason: Leadership in Africa." Public Administration and Development 21, issue 2 (May): 77-87.

Goodwin, Jeff. 2001. No Other Way Out: States and Revolutionary Movements, 1945-1991. New York: Cambridge University Press.

Gurr, Ted R. 1993. Minorities at Risk: A Global View of Ethnopolitical Conflicts. Washington D.C.: UsIP.

- 2000. People versus States: Minorities at Risk in the New Century. Washington D.C.: USIP.

Habyarimana, James, Macartan Humphreys, Daniel N. Posner, and Jeremy M. Weinstein. 2007. "Why Does Ethnic Diversity Undermine Public Goods Provision?" American Political Science Review 101, no. 4 (November): 709-25.

Hale, Henry. 2008. The Foundations of Ethnic Politics: Separatism of States and Nations in Eurasia and the World. New York: Cambridge University Press.

—. 2010. "Isolating Ethnicity: Some Challenges Involved in Assessing Ethnicity's Effects." Paper presented at the Ethnic Politics Workshop, George Washington University, Elliott School of International Affairs, Washington, D.C., October 15.

Hegre, Håvard, and Nicholas Sambanis. 2006. "Sensitivity Analysis of Empirical Results on Civil War Onset." Journal of Conflict Resolution 50, no. 4 (August): 508-35.

Horowitz, Donald L. 1985. Ethnic Groups in Conflict. Berkeley: University of California Press.

Jackson, Robert H., and Carl G. Rosberg. 1982. Personal Rule in Black Africa. Berkeley: University of California Press.

Kasozi, A. B. K. 1994. Social Origins of Violence in Uganda, 1964-1985. Montreal: McGill-Queen's University Press.

Lacina, Bethany, and Nils Petter Gleditsch. 2005. "Monitoring Trends in Global Combat: A New Dataset of Battle Deaths." European Journal of Population 21, nos. 2-3 (June): 145-66.

Langer, Arnim. 2004. "Horizontal Inequalities and Violent Conflict: The Case of Côte d'Ivoire," CRISE Working Paper, no. 13. Oxford: CRISE.

Lemarchand, René. 1972. "Political Clientelism and Ethnicity in Tropical Africa: Competing Solidarities in Nation-Building." American Political Science Review 66, no. 1 (March): 68-90. 
. 1994. Burundi: Ethnocide as Discourse and Practice. Washington, D.C.: Woodrow Wilson Center Press.

Lelyveld, Joseph. 1982. "Mugabe Government Confiscates Property Owned by Nkomo Party.” New York Times. February 17.

Lichbach, Mark I. 1995. The Rebel's Dilemma. Ann Arbor: University of Michigan Press.

Luttwak, Robert. 1968. Coup d'Etat: A Practical Handbook. London: Penguin Press.

Lyall, Jason. 2010. "Are Coethnics More Effective Counterinsurgents? Evidence from the Second Chechen War." American Political Science Review 104, no. 1 (February): 1-20.

Mamdani, Mahmood. 1996. Citizen and Subject: Contemporary Africa and the Legacy of Late Colonialism. Princeton: Princeton University Press.

Mason, T. David, and Dale A. Krane. 1989. "The Political Economy of Death Squads: Toward a Theory of the Impact of State-Sanctioned Terror." International Studies Quarterly 33, no. 2 (June): 175-98.

McGowan, Patrick J. 2003. "African Military Coups d'État, 1956-2001: Frequency, Trends and Distribution." Journal of Modern African Studies 41, no. 3 (September): 339-70.

Migdal, Joel. 1988. Strong Societies and Weak States: State-Society Relations and State Capabilities in the Third World. Princeton: Princeton University Press.

National Reconciliation Commission. 2004. National Reconciliation Commission Report. Accra: National Reconciliation Commission.

Omara-Otunnu, Amii. 1987. Politics and the Military in Uganda, 1890-1985. New York: St. Martin's.

Posner, Daniel N., and Daniel J. Young. 2007. "The Institutionalization of Political Power in Africa." Journal of Democracy 18, no. 3 (July): 126-40.

Prunier, Gérard. 2009. From Genocide to Continental War: The "Congolese" Conflict and the Crisis of Contemporary Africa. London: C. Hurst and Co.

Reno, William. 1995. Corruption and State Politics in Sierra Leone. New York: Cambridge University Press.

- 1998. Warlord Politics and African States. Boulder, Colo.: Lynne Rienner.

Reyntjens, Filip. 2009. The Great African War: Congo and Regional Geopolitics, 1996-2006. New York: Cambridge University Press.

Roessler, Philip. 2010. "Internal Rivalry, Threat Substitution and Civil War: Darfur as a Theory-Building Case." Manuscript, University of Oxford.

—. 2011. "Online Appendix "The Enemy Within." At www.philiproessler .com/publications.

Rothchild, Donald, and Michael W. Foley. 1988. "African States and the Politics of Inclusive Coalitions." In Donald Rothchild and Naomi Chazan, eds., The Precarious Balance: State and Society in Africa. Boulder, Colo.: Westview Press.

Salehyan, Idean. 2007. "Transnational Rebels: Neighboring States as Sanctuary for Rebel Groups.” World Politics 59, no. 2 (January): 217-42.

Sambanis, Nicholas. 2004. "What Is Civil War?" Journal of Conflict Resolution 48, no. 6 (December): 814-58.

Titley, Brian. 2002. Dark Age: The Political Odyssey of Emperor Bokassa. Montreal: McGill-Queen's University Press. 
Van de Walle, Nicolas. 2009. "The Democratization of Political Clientelism in Sub-Saharan Africa." Paper presented at the Democracy and Development in the Middle East, Conference in Honor of John Waterbury, Princeton University, April 2-3.

Wimmer, Andreas. 2002. Nationalist Exclusion and Ethnic Conficts: Shadows of Modernity. Cambridge: Cambridge University Press.

Wimmer, Andreas, Lars-Erik Cederman, and Brian Min. 2009. "Ethnic Politics and Armed Conflict: A Configurational Analysis of a New Global Dataset." American Sociological Review 74, no. 2 (April): 316-37.

Yeebo, Zaya. 1991. Ghana: The Struggle for Popular Power. London: New Beacon Books.

Young, Crawford. 1994. The African Colonial State in Comparative Perspective. New Haven: Yale University Press. 